\title{
Manu Joseph's the Illicit Happiness of Other People: A Critical Analysis of the Literary and the Thematic Features
}

\author{
Dr. TK Pius \\ Associate Professor of English St. Aloysius College Elthuruth PO Thrissur, Kerala India- 680611
}

\begin{abstract}
This paper on the thematic and literary features of Manu Joseph's The Illicit Happiness of Other People [1] attempts to grasp the semantics of novel's sophisticated entertainment as it unravels a quirky and darkly comic take on domestic life in southern India, illuminating a culture and an age. The paper follows the conventional method of introducing the author and his work, situating it in the context of the author's own life and career, and in the larger context of Indian Writing in English. A major portion of the paper showcases the book's technical, thematic and literary traits which ensured its singular achievement in the art of fiction writing. There are a number of brief reviews on the book revealing readers' appreciation and spontaneous reaction to the psycho-social and philosophical questions posed in the novel. However, I believe this is the first serious paper of its kind on the novel, which attempts to feature its strengths through textual evidences and analysis. Manu Joseph's book shows a unique advancement in the direction of experimentation with narrative technique that aids an amazingly accurate depiction of reality.
\end{abstract}

Key words: Characterization - structure - narrative technique - satire - humour- nihilism

\section{Introduction}

Joseph was born in Kottayam, Kerala, India and grew up in Chennai, where he graduated at Loyola College. After having dropped out of Madras Christian College, he became a staff writer at Society magazine. He has been the features editor of The Times of India and has written for The Independent and Wired. He is the current editor of Open magazine and a columnist with the International Herald Tribune, the global edition of the New York Times. Manu Joseph lives in Delhi.

His first book, Serious Men [2] is a darkly comic novel on a dalit living in a slum of Mumbai who gets work at a research institute but is full of resentment against his boss and other scientists from the Brahmin caste. It won the Hindu Literary Prize in 2010 and the PEN Open Book Award for the novel in 2011. It was also included in Huffington Post's ten best books of 2010 and was shortlisted for the Man Asian Literary Prize in 2010 and the Bollinger Everyman Wodehouse Prize in 2011. This book aided Manu Joseph to yahoo his way into the closed world of Mumbai's scientific establishment and knock the pants off the Serious Men (and one woman) inhabiting its sacred corridors, with a glee that was as riveting as his slum-side views of the Other Mumbai. Instant recognition accorded to him with rave reviews and awards have sobered a more cautious writer.

He reinvented himself as a south Indian Holden Caulfield, seeking the ultimate questions in the TamilBrahmin milieu of Madras, in Joseph's second novel, The Illicit Happiness of Other People. This book which was among the fifteen works long-listed for the fourth edition of the DSC South Asian Literature Prize is about an alcoholic's probe into the minds of a brilliant adolescent cartoonist's dangerous interpretation of absolute truth, an inner circle of talented schizophrenics and the pure love of a twelve-year-old boy for a beautiful girl. Ousep begins investigating the extraordinary life of his son, but as he proceeds closer to the truth, he unravels a secret that shakes his family to the core. The reader is also introduced to domestic and adolescent life in contemporary India in the course of the probe. This semi-autobiographical novel was described by The Wall Street Journal as a work that, "injects dark, rueful laughter into an immensely touching story of loss." [3]

\subsection{Context}

Joseph is currently being lauded as one of the leading lights in the new wave of Indian authors that are adding to the literary wealth of the English language. His two remarkable novels point to a new direction after the earlier wave of writing by Salman Rushdie, Rohinton Mistry, and Vikram Seth. Aravind Adiga did class resentment really well in The White Tiger [4] while Rana Dasgupta does metaphysics as well as the great European modernists in his Solo. [5] Put these two elements together, and add the relentless satire of Mohammed Hanif in A Case of Exploding Mangoes [6] and you get Manu Joseph's novels

Though Joseph falls in line with the tradition of Metaphysics and satire, it is hard to imagine he was emerging from any literary tradition. He admits in an interview "I don't think Indian writing in English is a formidable thing right now for anybody to have to rebel against. Clearly, considering my view, I was not 
emerging from any literary tradition."[7] In a sense, that was actually an advantage. His two novels show that if he was ever to write these novels he would have written Serious Men and The Illicit Happiness of other people only this way. One thing that unites these books is a supreme confidence that Indian writers can chart their own literary destiny without regard to prevailing fashions in the West.

While Manu Joseph's first novel was a satirical one on India's elite scientific institutions, the second one, The Illicit, which he came up with just a year later, is an absorbing psychological thriller. The main characters - a morose and emotionally withholding drunk of a husband and father, a resentful and mentally unstable housewife who is too smart and educated for her life, an arrogant and cruel teenager who kills himself, a hapless younger brother who is no more than a stock character- which are deep, intriguing and strong personalities, impart the glue which hold the story together. It is difficult to bracket this work into a specific genre. It is many things - a thriller, a sharp commentary on society, culture and religion, a dark comedy with a wicked take on existence and morality, a poignant human story and sometimes, even a profound look at the mystery that is life and the human search for truth. There are two Malayalam movies this book reminds the readers of - Sphadikam for the name Thoma Chacko and the cutting of shirt sleeves; Kathavasheshan for the theme - the flashback from a suicide and the search for the reason, and, in a very loose way, the reason itself. This book would be especially interesting to pair up against something like Fae Myenne Ng's Bone [8], since both novels deal with the ramifications of a character's suicide, but go about exploring this topic in very different ways.

Manu Joseph shares with some of the Indian writers one peculiar quality, which is, they powerfully demolish our social pretensions in a very empathetic flourish of their pen, without throwing any of those pretensions to erudite ridicule or literary snobbishness. Their writings, including Joseph's underline a certain universal humanism that is utilized to denude Indian society, especially its middle class. In fact, Joseph's portrayal of India rings true, with abundant insights into culture, class, and daily life. He lays bare a nondescript middle class colony in Madras where "all men are managers, all women are housewives and all bras are white" [9] and where lives the dysfunctional Chacko family. Joseph has already proven himself as a punch line king in dropping compact and satiric wise-cracks that turn inside out, the objects of his aphoristic treatment. "He had two children, a girl and a boy, which emphasized his normalcy"[10] explodes inside your mind like a thought bomb that suddenly exposes an ever-present, yet invisible truth about our middle class families. "It is the misanthrope alone who has clarity" [11] also indicates a shared sentiment of these tribe of writers, who employ justifications for stark cynicism, not to shower despondency, but to bring out an alternative perspective that is already there, but not yet observed because of our illusions formulated through centuries of blind social and cultural inculcation. "In the fog of ambiguities and mysteries, he desperately searches for truths because truth usually shows humanity in a poor light." [12] Manu Joseph has, with this book ensured his place amongst those Indian writers who have achieved brilliance in holding up mirrors to ourselves, in a playful manner while refraining from didactic skulduggery.

The novel also explores a number of questions that engages the reader intellectually. Joseph tells Shivani in an interview that the novel "...has the appearance of high art, high science, but it is actually in the realm of entertainment". [13] Questions about connections between perception, philosophical quest for meaning and what is known as psychological disorder are all the inevitable part of the book. How much imaginativeness and quest for knowing what is beyond our immediate existence is normal? Could it be that people with so called psychological disorders actually have enhanced senses and perceive what is beyond the "normal"? Does a person with malfunctioning senses perceive the world and its meaning in a different way altogether? Is there a concept of absolute sanity or is it merely defined as the level of thought and understanding possessed by the multitude?

It is hard to say just what sort of book The Illicit is. In part, it is a psychological thriller, and in part it is dark comedy; then again, in part it has the cavernous poignancy that has come to characterize the very best dramatic fiction of our times. It probes moral and philosophical quandaries with stupendous depth, and then quickly pivots into searing satire. At every point, it is thought-provoking and gently remonstrative. The book comes as a reminder when we need it most that despite the many transformations of the world, there is still something very wrong with the way we bring up our sons.

\subsection{The Sources}

Joseph explored the idea of being a man as a psychiatric condition. This exploration led him to weave together the theme of the quest for meaning, the suffocation of pre-liberalisation India, that hopeless time when an engineering degree and an escape to the US was the only acceptable dream for young men from a certain middle class milieu, and the everyday cruelties inflicted on Indian girls, to create this never-coming-of-age novel set in 1990. Despite the exploration of nihilism, of concepts in psychiatry and spiritualism, and the acute social commentary, the story, which Joseph reveals grew out of his own experience and that of people he knew intimately, never meanders. 
"It's largely biographical and somewhat autobiographical," he says admitting he was initially "too shy to write it". Manu Joseph told his interviewers , "It's all real, I haven't made up anything,"... [14] The background hum of The Illicit is "the Madras I grew up in and this background is not fictionalized. If it were, I would have been whipped by now by the very clever Tamil population all over the world. I re-created this world because it was important for the story" [15]. Intriguingly, Joseph repeatedly hinted in media interviews that, when concerned with the characters, nothing is apparently made up. There's certainly a deep and convincing sense of knowledge, sympathy, and wisdom in the lives portrayed; it is the Chacko family that really holds the forefront of the reader's attention from start to finish.

After Serious Men Joseph understood that one can derive ones most powerful stories from things one knows very well. "It was inevitable that I would tell this story" [16] he says reminiscing about his teens when he was part of a group of boys much like the trio in the book. Joseph suggests that some who ponder too hard about the ultimate pointlessness of existence never escape the mental minefields of adolescence.

This is primarily a story well told through unforgettable characters and Joseph is right in referring to it as a mystery novel. "To me, the shell and the message are equally important. And I wanted to tell this story by taking characters through the process of investigation and resolution: to me, it's a mystery novel. But the starting point was my interest in the humour and the melancholy of pointlessness." [17] Indeed, there is much psychological mystery and the involved reader gets baffled at Unni's actions as his father, the remarkable Ousep Chacko, banished journalist, failed writer and noisy drunk who has "gone too far the Malayalee way".

This story could have held true in any urban setting but then the place where it is set becomes a character in its own right. "This particular story, inspired by events that happened in Madras at a particular time, belongs to Madras and Madras alone. The time when the events occur, too, was inescapable for the same reason. Time, too, is a character." [18] He believes that a novel should either concoct events and places, or be true to facts, be journalistic. When he describes a place in a novel, he wants it to assume its real name only if he has been accurate about everything about it." I grew up in Rajaram Colony in Kodambakkam and Balaji Lane is derived from that. I did not name it Rajaram Colony because around the years when the novel is set, there wasapart from four identical red-and-white buildings - a cow shed and some independent houses, which were distractions I did not need in my novel. So I made it Balaji Lane where there are only the four buildings. [19]

The author was not quite concerned about his influences. All what he wants is " to write about relationships between men and women, which is the only thing that matters in this world and it covers everything that we try to do. And, of course, I want to explain time and again the sweet melancholy of pointlessness. No writer has influenced me, and I don't know why. I love some writers but they don't influence me." [20] Yet in a conversation with Arjun Singh, Joseph mentioned his two influences in writing: "If Marquez is one end of the spectrum - I'm only talking about the good stuff now - Coetzee would be the other end, and what we call good literature would fall between those two poles. I'm also influenced a lot by cinema; I use melodrama when I have to use it. As an Indian I'm not afraid of it. That's another thing about the corruption of western publishers - that's a society that doesn't comprehend melodrama like we do. When I see too much sensitivity and elegance and sophistication, I get impatient".[21]

\section{Literary Features}

The Illicit is immensely rich in literary features that a serious scholar of literature would find it particularly enriching experience concerning the art of entitling, plot construction, characterisation, narration, parody, humour, satire and generation of psychological and philosophical mystery. These, the author handles, in a way which is entirely his own, founded on his thorough straightforwardness and grit.

\subsection{The Title}

Structurally,the title The Illicit Happiness of Other People follows the fashionable formula begun by Kundera (The Unbearable Lightness of Being [22] ) and continued by writers such as David Mitchell (The Thousand Autumns of Jacob de Zoet [23] ) The book's title, is also a trifle too reminiscent of Rahul Bhattacharya's The Sly Comfort of People Who Care [24] But thematically it suggests drawing happiness out of the forbidden corners of mental inabilities, camouflaged feelings of sensuality and attempts to draw an acceptable image of unacceptable past. In The Illicit the one in search of happiness fades away in the sentiment of shame. The girl left behind with his dreams struggles to make peace with the event. The one who wants to unwind the truth refuses the realty. The one who is the origin of all, the mother, sits back as the moving force for all the events but remains passive herself. Perhaps ironically, Serious Men is not at all "serious" whileThe Illicit seemed anything but "happy".

Joseph reveals in an interview with iSahitya that the novel was originally titled, "Mariamma Wins" - at a time the novel was chiefly about the fierce battle between a man and his wife. But as the book progressed, the story transformed and the strands that he initially thought were minor became the key plots." In one of the earlier versions of the novel, Ousep Chacko has a controversial column in a Malayalam weekly. Ousep got the 
idea of the column from one of Unni's disturbing questions- what if those who are supposed to be miserable are actually not so miserable. Ousep, every week, interviews a person who is deemed by the society as unfortunate, and argues that he or she is fine, even happy. Ousep writes the column to annoy the regular, normal people, his readers, with the possibility that there is no great fortune in their own lives because there is no hierarchy of happiness - most people in the world are more or less happy in the same way. The title of his column was 'The Illicit Happiness of Other People'. [25]

Unni, the central character of the novel tells his mother: " People want to be happy, don't they?' ...'They are desperate to be happy, aren't they? But look at how many things have to go right in a person's life for that'... But still ... in this world, it is very hard to escape the happiness. That's how it is." [26] Unni Chacko believed that happiness was inescapable What could persuade a seventeen-year-old boy with an extraordinary personality and unusual levels of intelligence and self-possession to take his own life - especially when he is convinced that happiness is his unavoidable destiny? Unni Chacko believed that happiness is inescapable, that human beings have a genetic predisposition to being happy. Illicit Happiness is a hard look at the pursuit of happiness. Ousep's interrogations rupture the timid propriety of a social structure that longs to forget its anomalies. The story of a nun at St. Theresa's convent who was put there by her parents to save her from poverty proves Unni's point. After she was sent to the convent, she ran back home twice. But when she was sent back the third time she accepted her fate. Now after years in the semi-cloister convent, she looks fine and happy. ' That is Unni's hypothesis - the inevitability of happiness, the persistence of happiness. Happiness is an inescapable fate, not pursuit.' [27]

For a book with 'happiness' in its title, it certainly juggles some hefty drama. The story, after all, is that of a mourning father trying to understand his son's suicide. But Joseph says that he is less interested in the dull and dreary, both in life and in literature."I'm a very pleasant person," Joseph says. "I rate myself as very happy." And, he adds, happiness may be a bit underrated. "There are a lot of artists who have made a good living from melancholy," Joseph says. "Their gift is that they're able to absorb a lot of shit and write about itgrim, dreary things. And I look at them with a lot of suspicion, and I try to understand, is there a literary value here or is it the value of sorrow?" [28] Indeed, with Happiness, Joseph has made a convincing case for exploring the depths of joy the way so many of his predecessors have plunged into melancholy.

The question is whether happiness becomes illicit when its sources are the neighbour's / reader's own voyeuristic peep at the terribly sad story of a family coping with a tragedy that has no apparent rationale. Each of the three most affected are islands in their individual sorrow as they try to wear a mask of normalcy for the others. On the other hand, this novel itself smart, wry, and poignant teases the reader with its mystery, philosophy, and unlikely love story. The buffoonish but dogged investigation conducted by Ousep into his son, Unni's motivations for committing suicide maintained a steady suspense and keeps egging the reader on and discover what lay ahead. The book offers quite an intimate view of a family, so much so that one tends to feel voyeuristic for knowing too much about the family's failings, like for example when Mariamma does not raise her hands up at a congregation because her blouse was torn at the armpits. The interactions of all the major characters also embellish the concept, illicit. For instance, Thoma one of the sons of Ousep Chacko feels 'an irresistible urge to laugh' [29] when he listens to the grunting voice of his drunken father replaying his conversation with the doctor he visited. Ouseph plays out 'the obituary of a failed writer' when he attempts to hang from the hook of the fan using his lungi as a hangman's noose. He loses his balance and wobbles for a moment on the chair. This action "brings a terrifying burst of laughter' '[30] to Thoma but he would not.

The novel could be about "a flicker of triumph... in the eyes of other men" [31] whom it would please so much chew on other's misfortunes to moralize and justify their own unconcerned and callous ways. This could also be "because what men find most endearing in other men are their tragic flaws'. [32] Again, people seem to have a faint "triumph in their voices when they speak of Unni's death..."[33] The novel is about those "other people" who don't even recognize their life altering impact on the people they passed through. Their happiness is the truth. Rest all around it is an attempt to indulge in the depths of one's own understanding in a vain effort to find its reasons. The author seems to be laughing at reader as one progresses through the story. Why would one read all the idiotic philosophy the boy ('the other' ) seems to have discovered and still continue! And yet the reader turns to these pages in the hope that he can gaze at the boy who is somehow creating his happiness in the dark background that he belongs to, and satisfy his voyeuristic pleasure or in the hope that the illusion of mind can overpower the imprints of facts that it denies or in the hope that a parent can make peace with the loss of his/her child once convincing reasons ('the other'), constructed/ real, overpower the sense of loss. And hence the title The Illicit Happiness of Other People .

\subsection{Setting and Time}

The Illicit, is the story of a Malayali Catholic family living in a Madras housing colony - a milieu Joseph captures with an exuberant, Hogarthian exactitude - among a mixed community of Catholics, evangelical converts and Hindus though dominated by Tamil Brahmins which takes place in the late 1980s. To 
be more precise, it is Madras in 1990, flashing back to 1987. The Words like perestroika, GATT take us straight back into the 1990s in the context of pre-liberalisation and Mikhail Gorbachev being elected the executive president of the Soviet Union. It is set in Balaji Lane that has four residential buildings named A, B, C and D, starring a family that is peculiar despite efforts to be normal.

Joseph portrays its neighbourhood where all boys, from the time they're born, share the common destiny of sitting for the JEE exam, which will determine the trajectory of the rest of their lives. If they pass they'll get into engineering college, go to the US, get a Green Card, and live happily ever after; if they fail, they're doomed to study physics, and end up working for Canara Bank, like their fathers, riding a scooter to work, and returning to their pious, jasmined wives each evening. It's a universe where you might get beaten by your father for getting only 90 per cent in the exams, and a typical adolescent conversation goes: "Tan 2 is equal to?" "Simple da, two tan $\mathrm{x}$ by one minus tan square $\mathrm{x}$..[34] But Unni Chacko was different. Very different. Manu Joseph lashes out at Madras in searing prose, taking his anger out on the great city and its remarkable stupidities in a way the reader will remember for some time. Not only does Madras come alive, the author ensured it hangs its head in shame. Madras is as much a character in the book as anyone else, redolently waxed into the details with blithe humour. This is no nostalgia of the romantic. It is also very successfully taken apart at times, as Joseph turns a really scathing look on his community's sexual hang-ups, social and religious peccadilloes and more. Joseph exposes the many hypocrisies of Madras on the same canvas as its beauties.

\subsection{Plot}

Manu Joseph's The Illicit, treads a path very different from his first one, Serious Men. The Illicit revolves around the Chackos, a Catholic family living in a gossipy Madras housing community in the late 1980s. The Chackos are the Keralite immigrants to the southern metropolis. This dysfunctional family seems to have no place in the quiet faux-perfection of Balaji Lane - they are "the cuckoos among the crows." [35]

Unlike Serious Men which revolves around class/caste differences, The Illicit merely sets out to tell a story. It is an admirable blend of plot and ideas, of a story that reads like a mystery but also of the kind of philosophical and social observations that are worth pausing for and underlining. Very early in the book, we are told that on the 16th of May 1987, Unni Chacko, son of Ouseph and Mariamma Chacko, the gifted but troubled teenager mysteriously fell from the balcony of his building. He was seventeen. His death was a puzzle to everyone because, "... if there was a person in the world who was sure of his every step it was that boy"[36] It was an obvious instance of a suicide as the six eye witnesses testify: "... Unni stood on the railing, composed and in control. He stopped for a moment, crossed his hands behind his back and plunged down."[37] Before the burial ceremony the priest has an aside with Ouseph on Unni, " The boy, he was a good boy deep inside. But he was not normal ... Some boys wander far. There is nothing we can do about it" [38] Others say, "he was drifting towards dark thoughts, he was too clever for his age" [39] His father Ousep, mother Mariamma, and youngest son Thoma are left to deal with hard, seemingly unanswerable questions as a result of Unni's passing. Did the teenager willingly kill himself? Why didn't he leave a note behind explaining his action?

When Unni's alcoholic father Ousep gets a delivery from the post office - one of Unni's drawn comics, lost in the mail - he is jolted out of his stupor and embarks on a solitary quest to understand his son and rewrite his family's story. Thus the novel starts three years after Unni's death and moves backwards. There's no question that Unni had some strange quirks, but it's not clear to Ousep whether his views and behaviour were unconventional or bizarre enough to sustain a diagnosis of schizophrenia. Ousep's acquaintances now begin to ask him: " Why have you started probing again?... Why are you doing this now? After three years? [40]

Unni had shown some talent as an artist, especially as a cartoonist. So Ousep starts to scrutinize some of his son's cartoons, hoping to find hints of his fate. a bizarre twist has convinced Ousep that the mystery of Unni's life and, therefore, his death can only be unravelled by deciphering the comics that Unni illustrated, several of which are generously described in the pages of the book. In fact, so intriguing and clever do they seem that one wishes sketches and comic strips had been included in the book. But these are petty quibbles that take absolutely nothing away from Joseph's wry and multi-layered tale.

He analyses "...every inch of the sixty-three cartoons and comics by Unni that lies about the house, most of them in a wooden trunk. Sixty-four if Ousep includes one inexplicable comic that has landed by chance in his hands, which he has hidden from Mariamma"[41] He believes that the only clue to his action of suicide lies in these comic strips he has drawn. Like Jack in Anita Nair's Lessons in Forgetting [42] who cannot rest until he gets to the truth of Smriti, a tragic embodiment of memory and past violence, so is Ousep drawn more and more to the Mystery of Unni's death.

In one disturbing series, Unni depicted friends and family as corpses, and he had cryptically confessed to a friend: "I know a corpse." [43] Another series also preys on Ousep's mind, a sequence of cartoons with "bubbles" for dialogue, though Unni had not had time to ink in the words, so the story he intended to create remains forever perplexing and elusive. The narrator explains Unni's action and his comic strip: "Seeing corpses in their coffins probably inspired his longest work, The Album of the Dead. As it progressed he showed it to 
several friends, who were disturbed by his idea of humour. In the Album, he imagined family, friends and other familiar people dead in their coffins. Every person has a whole vertical page, and there are thirty-two caricatures in all, including a self-portrait." [44]

In trying to comprehend cause post-effect, Ousep (and Joseph) leads the reader into a paper chase that goes from the trite - a homosexual teacher who is publically trashed for his transgressions - to the downright paranormal. Ousep pursues, prods and harasses people whom Unni had known or met to collect the puzzle pieces to solve a mystery that was his son. " People have lot of things to say about Unni Chacko, they show his world as a surprisingly large place but nobody can explain his final act." [45] Ousep becomes convinced that the secret of his son's demise lies with two of his friends, Sai and Somen, so he pursues them relentlessly, almost to the verge of stalking. He pumps them for information that they're unwilling to yield - though perhaps they know nothing at all. Ousep begins to haunt Somen's house at all hours, trying to catch a glimpse of him and engage him in conversation, but Somen's parents continually deny that he's home. Finally, at the end of the novel, Somen emerges from his room, where he has remained for the previous two years, to explain to Ousep Unni's unnerving and elliptical take on reality. In the course of his search "Ouseph wonders whether anyone truly knows why his son died, if a day will ever come when he finally solves Unni"[46]

A journalist working for the news agency UNI, an atheist and a drunkard, Ouseph's main success lies in not behaving or even resembling his middle-class neighbours who he thinks are either bank clerks or have much in common with bank clerks. His "stranded wife" Mariamma on the other hand is very religious and godfearing though a fiercely protective woman who has long-suffered Ousep's nightly alcohol-induced obstreperousness.

Matiamma and Joseph had lived entirely a different life earlier when they were young: they were socialists ..." like all informed young men and women of the time, slim people in love who thought they knew how to make the world a better place, a place as happy as their beds." [47] But what holds them together now are poverty, shame/shamelessness and a will to live on. Meanwhile, the family's debts to their neighbours remain unsettled, their credit account with the Sacred Heart Family Store mounts, and the rubber slippers they wear grow ever thinner, held together now with safety pins.

Mariamma, tries to protect her younger son, Thoma, from Ousep's harmless but humiliating alcoholic rages by instilling confidence in him saying, "Be strong Thoma, don't be afraid. I am here."[48] or " Don't be afraid. I am the Rock, Thoma, and I shall never fall" [49] Meanwhile, Ousep's fixation impacts Mariamma. The first sentence of the novel gives ample evidence to this: "Ousep Chacko, is the kind of man who has to be killed at the end of the story"[50] Mariamma talks to herself/ "to her bare walls all her reasonable grudges". [51] She "bites her lip with a ferocity that makes her head tremble and her eyes look interested. she stands facing the bare yellow wall and she wags her index finger. She tells the wall, in quivering voice, about Ousep's mother and his nine sisters ... She gets into this state sometimes and when she is this way she loses her sense of the world around her". [52] She even wishes for her husband's own extinction. Ousep was blissfully unaware that his long-suffering wife was plotting to kill him. Also affected is their young son, Thoma, who on the cusp of adolescence, is terrified of nearly everything. He is drawn to the older girl next door, who holds her own secrets about Unni.

Unlike Ouseph and Mariamma's characters which are very realistic, as is that of second son Thoma, Unni is a caricature artist. Unni is very good-looking and his thoughts and actions are not that of a highersecondary school-going teenager. To top it all, he is a talented cartoonist. Very early on in his life, Unni realises that he is different. Or rather, he starts believing that he is different. From then on, in addition to making cartoons which are acclaimed by many, Unni starts exploring his own mind. A precocious boy who learns to exercise his power over others, Unni carefully picks Somen Pillai and Sai Sankaran as his friends. Somen believes he is a corpse and Sai is in awe of Unni and Somen and lets them both experiment on him. The three teens have awesome adventures with Unni and Somen having all the fun, usually with Sai's hair standing on end.

Unni is close to his mother Mariamma and is not exactly chummy with his father Ouseph. Yet when Unni dies, it is Ouseph who goes in search of the truth. Unni calls himself an atheist Hindu and yet he gets a Catholic burial at the Fatima Church. This despite the Church considering suicide to be a sin. As Ouseph searches for Unnni's past, we get nuggets from Ouseph and Marriamma's earlier lives as well. Also the fissures in Unni's story are slowly revealed. What Ousep discovers, after interviewing Unni's friends, fellow artists, teachers, and anyone else he can track down, is a deeply thoughtful teenager burdened by weighty existential quandaries. His journey takes him to places that uncover deeper family mysteries that impacted his wife's happiness and the discovery that the lost son is connected - emotionally and behaviourally - to that long ago event.

Ouseph used to be a popular journalist in Kerala, but was forced to migrate to Chennai after he broke the story of how a powerful archbishop in Kerala was also a paedophile. When Mariamma was twelve, she was molested by a local lad, Philippose. Philippose wasn't the local goon. Rather he was the nice young man who 
read the Bible during the Sunday service, sang in the choir, organised boat races and was liked by all. One day Mariamma confides in Unni the trauma she had undergone when she was young. Very soon Unni is on his way to Kerala to meet Philippose and confront him. Unni does not manage to meet Philippose for he was dead a few years ago.

Unni is a stud. Surrounded by classmates who are busy cramming for the IIT- JEE and other exams, Unni immerses himself in his cartoons. The pretty girl next door Mythili Balasubramanium has fallen for Unni. The character of Unni would remind the reader of an article written by Joseph many years ago about the designer Anand Jon. There are a few similarities in Joseph's description of Anand Jon and his portrayal of Unni Chacko. For instance, like Unni " Anand John was the event. Everybody began to discuss him and word soon spread that he had this magnetism, that he could somehow detach girls from their precautions and make them go astray. .. Anand John was a great talent. His sketches were breathtaking." [53]

Towards the end, Ouseph Chacko has a long and very interesting discussion with Dr. Iyengar, a Neurosurgeon and Neuro-psychiatrist, who runs the Schizophrenia Ward at a non-descript mental hospital. Dr. Iyengar has had dealings with Unni in the past and hence Ouseph's interest in Dr. Iyengar. In the Acknowledgements section, Joseph tells us that he met with neurosurgeons and neuropsychiatrists as part of his research of this book and so we can assume that interesting details of conditions such as Schizophrenia and the Cotard Delusion are factually correct. Through the words of Dr. Iyengar, Joseph tells us that Godmen are not conmen. Rather, Godmen actually believe what they say. When a Godman claims to be God or to have a connection to God, he actually believes it himself. Without such self-belief, a Godman would not be able to convince others of his powers. Joseph speaking about Sri Sri Ravi Shankar, the founder of a movement called the Art of Living says " As in the case of many self-proclaimed Indian gurus, Mr. Shankar's success lies not in deceiving others but in convincing himself that he is an extraordinary entity".[54] Joseph's interview of Sri Sri Ravi Shankar provides for more of his views on Godmen.

Mass delusions ,cartoons, teenagers at the cusp of adulthood, an investigative father who is also a drunkard journalist, a schizophrenic mother, a day dreaming, timid young boy, a pretty girl next door, typical curious middle class residents resigned happily to their humdrum lives, a patriarch in psychiatry, Madras, Syrian Catholics, Kerala --these are the key subplots that revolve around the whydunnit suicide of a philosophically minded teen cartoonist who is in attitude and behaviour, stronger and wiser than any of the other characters in the novel.

One clue to all these psychological themes that Manu Joseph offers in his afterword is his indebtedness to Dr Ennapadam S Krishnamoorthy and his theories on the "God Particle". Along with VS Ramachandran's epochal work on the primordial areas of the brain, which he wrote about in Phantoms of the Mind, [55] these sorts of subjects have often been of interest to people in Chennai. In writing Unni's case history, Joseph seems to ask, how close is the god particle to the demonic one? That Joseph is able to touch upon such weighty matters while wrapping them in up the garb of a family saga is what makes him a clever writer

Manu is successful in keeping the plot complex, which is the mark of a good thriller. He also adds layers of philosophy and neuropsychiatry. Since the book is about the death of a young boy, much liked by his near and dear ones, there is melancholic strain to the narrative. One comes across many 'failed personalities' including Ouseph Chacko whose potential 'decayed in gentle happiness', Mariamma - though a wise and quickwitted lady is still troubled by an her past, and Thoma who bears the burden of living up to the high standards left by his brother. The author with his very incisive observations of people and places laces the narrative with sharp satire and wit.

While the reason for Unni's death is perhaps answered as best as it ever will be, Ousep's search for answers - ever the inquisitive journalist - does not cease. While he has learned more about his son after his death than he ever knew while Unni was alive, Ousep still hungers to know more, to learn how Unni saw the world - as a place full of delusion and overwhelming happiness - in a culture that believes unless you pass a school test, you are doomed to a second-class existence. Ousep's journey takes him through the world of school and standards, expectation and reality, and to corpses and the living. The final impression the reader gets at the end of it is that it is a stylishly written book, which starts out as being darkly comical, and then grows progressively darker and more disturbing, as Ousep Chacko pursues the mystery of his beautiful, radiant son, peeling the onion, layer after layer until he finally arrives at the sad, shameful nothingness at its heart.

\subsection{Characterisation}

While the construct is remarkably simple, the author is a master at de-constructing the lives and personalities of nearly each character. Each character is like piece of a big jigsaw puzzle, a small piece of the bigger picture. The family of Chakos has Ousep, the alcoholic news reporter father, Mariamma, the mother who talks to the walls, Thoma, the younger son at the brink of adulthood and Unni the elder son, a cartoonist and whose death is the big Question. In the course of the novel, Ousep Chacko encounters an intrepid group of cartoonists, Dr Iyenger, a neuroscientist, , a corpse, and a whole host of other idiosyncratic characters - 
Mythilli, Philipose, Balki, Sai, Beta, a man who thinks he is a dead body, a nun who has taken an oath never to speak, and many more - who sound as though they may have stepped out of a Wes Anderson movie but are, in Joseph's hands, perfectly reasonable everyday individuals. The novel is a journey through the minds of various individuals who remind us of our frailties, small successes, huge fears and our will to always be happy

The characters are unique in their portrayal and impart the glue which hold the story together. Manu Joseph has particularly proved to be an enormously talented writer with his ability to bring a world and a time to life with a few deft strokes. The characters he writes exude attitudes and sensibilities that the readers can immediately pick up on from the day to day life. And the book, with dark hilarity makes a loud laugh on the eccentricities of the human nature portrayed in the people who live within its pages. His remarkable powers of observation shines in this book in the way he has with tremendous flair sketched out even the most 'insignificant' of characters and even stereotypes for the biting humour. From a silent nun to a neuro-scientist, every character despite extreme quirkiness, is believable. The author's affection for his main characters is evident - because despite their faults and idiosyncrasies, the reader would end up feeling for them, and their plight. It is a tender portrayal of the anxieties and ambitions of Indian youths and the parents that watch them struggle with social pressures as they come of age as adolescents and young adults.

In The Illicit all the characters towards the end have Ousep's or Unni's narrative style, more or less. So, as the extra-ordinary became plausible, the characters themselves start to evaporate into one homogenous personality. Maybe there is really only one boy, Unni and all other boys are confabulations of the distraught father to resurrect him from the dead. Well, the reader needn't be so sure, it seems that is not the case when we ponder on the key figures. The main characters - Ouseph, Mariamma, Unni and Thoma who are revealed progressively - in it are deep, intriguing and strong personalities, making the reader look forward to what they would do next. Apart from the four main characters, this book is full of cameos - there was a Tarantinoesque influence in the structure. A very important character, a neuro-psychiatrist named Iyengar, is a cameo. The author admits in an interview that "If this had been my first novel, he would have had a prominent role right from the beginning because he is so important to the resolution of the novel: he is trying to prove that sanity is not a majority condition; that you cannot consider a majority delusion as accepted human nature. But while writing this, I was confident enough to bring him in towards the end." [56]

\subsubsection{Unni}

Unni Chacko the eldest son of Ousep Chacko is a force to reckon with being a hero and an anti-hero at the same time. He is a "cartoonist hottie" with a cosmic eye, a handsome prodigy of the comic strip world quite well known in the community, and is at the centre of the novel but he was already dead three years before the novel even starts. He was a seventeen-year old boy who expressed his comprehension of the world and pursuit of truth through his cartoons. " Most of Unni's works are comics, their stories told over several pages through elaborate black-and-white sketches with a sudden dash of watercolour here and there. There is no single theme that unites all his works, and there are no dark superhero stories as people might imagine. But for some reason, there is a disproportionate number of comics that lampoon the human search for the meaning of life". [57]

$\mathrm{He}$ is an ordinary student, ferociously fond of his mother, alternately tolerant and loving towards his kid brother; but like all young people, he has a secret life independent of his family. He also has a talent, or two: Unni is a cartoonist who hates filling in the speech bubbles. And he sees things that no one else does. He has a unique way of looking at the world-his insightful questions and his unconventional take on ideas and concepts, like the insulted French syllables, his understanding of the inevitability of happiness, the idea that truth is not an absolute fact, and several other such notions. Asked by the interviewer how he did character of Unni, Joseph says, " Unni is a bit of someone I used to know and what I used to be." [58]

Joseph wanted to come at Unni from various angles, through various people. One thing the reader might appreciate in the book is that everything one knows about Unni was through other people. Unni is thus placed at the centre though absent moving other charcters: his father compulsively seeks the reason for his young son's suicide; his mother wrestles with a mentally-debilitating memory; his younger brother struggles to make sense of a bewildering world. The enigma created around him throughout the story is very powerful.'Unni, what an idiot you turned out to be', thinks Mythili Balasubramaniam, and as the book unfolds to reveal the character of Unni Chacko, the readers too think the same.

Unni is very good-looking and his thoughts and actions are not that of a higher-secondary school-going teenager. Very early on in his life, Unni realises that he is different. Or rather, he starts believing that he is different. From then on, in addition to making cartoons which are acclaimed by many, Unni starts exploring his own mind. As precocious boy who learns to exercise his power over others, Unni carefully picks Somen Pillai and Sai Shankaran as his friends. Somen believes he is a corpse and Sai is in awe of Unni and Somen and lets them both experiment on him. The three teens have awesome adventures with Unni and Somen having all the fun, usually with Sai's hair standing on end. 
Unni is close to his mother Mariamma and is not exactly chummy with his father Ouseph. Yet when Unni dies, it is Ouseph who goes in search of the truth. Unni calls himself an atheist Hindu and yet he gets a Catholic burial at the Fatima Church. This despite the Church considering suicide to be a sin. When Mariamma, alone in the kitchen would gesticulate in a dream log on Ousep or Annamol Chacko or Philipose, Uni would change her mood and 'make her laugh and extricate her from the Torments of Memories. Unni would crack a joke and she would reclaim her pretty face from the angry scowl, and begin to shake with laughter' [59] One day when Mariamma confides in Unni the trauma she had undergone a girl, Unni goes to Kerala to meet Philipose and confront him. Unni's relationship with his mother is one that pushes him to explore questions of morality and agency: how does one act in a socially conscientious way and can an individual exert complete control over his or her desires?

Even as a small boy, Unni "thought too much, he was full of ideas" .[60] He loved talking about these to his mother. "As he spoke he ran his thumbs over her forehead, a habit he had picked up when he was around seven, believing that the lines on her forehead were worries and that he could make them vanish by straightening the creases". [61] He spoke to her about death but not in a dark way. He would ponder on the meaning of life." If he heard of a person who behaved in an extraordinary way, he would become very curious, he would try to find out more, even loiter near their homes.".[62] This could be one of the reasons why people thought Unni to be a bit odd.

Maiamma recalls the blind and deaf game that he used to play when Unni was small. "He used to pretend that he was either blind or deaf. He used to play it so well and for a long time that Mariamma would get worried. The days he claimed he was blind he would walk to school exactly like a blind child, holding her hand all the way and stumbling on things. And when he said he was deaf, he would not flinch even when he heard a sudden blaring horn on the road. Some days his teachers complained about this. But surely he was pretending, it was a game." [63]

An image of Unni assembles itself in Ousep's head, staring at a portrait of Unni in his house: "What Ousep sees is a boy with keen narrow eyes, a broad forehead and a high mop of thick hair. A seventeen-year-old cartoonist, an exceptional cartoonist, but too young to accept that subtlety is not always the mask of mediocrity. Like most cartoonist, the boy does not talk much, and when he does speak he is not very funny. Most of the time he is excruciatingly terse ..."[64] Beyond this Ousep knows very little about his son and possibly much less than most fathers.

From Ilango we learn about Unni's talent as a story teller. During free hours or lunch break, he would climb on the teacher's table and stand in silence until all eyes are on him. Then he would narrate his own stories. " When Unni told a story ... it was as if there was no other sound in the world. And as he spoke you saw pictures in your head, you saw faces, and you could smell thing that you did not know had smells." [65]

It seems there is nothing Unni can't handle, from his classmates to his mother's delusions, his father's drunken antics to his brother's anxieties. A gifted cartoonist, he's the one person in the novel who isn't burdened by the mania for academic excellence. Unni is the last person anyone expects would go the Humpty Dumpty way, but one day, inexplicably, he does. For the next three years, Unni becomes Ousep's study and the father's project of unconquerable Will is to figure out why Unni did that Terrible Thing.

He was a careless student, but a brilliant cartoonist, whose cartoons revealed strange, hitherto unknown secrets of the universe. He held his classmates and friends in awe, with a wisdom and authority far beyond his years. And, as if to punctuate his different-ness, he belonged to a Malayali family-cuckoos among the Tamilian crows of Balaji Street, as Manu Joseph describes them

Unni was a boy who: "thought too much, he was full of ideas". His comics and cartoons -- quite a few are described in detail -- are very clever and often explore philosophical conundrums. But Unni was also a strange soul, unlike all the other boys. Prone to act unusually, he was nevertheless respected; his quirkiness did not alienate him from his classmates. He also exerted a strong influence over others -- and often created situations so that he could observe how "others reacted" in them. .[66]

When asked if Joseph in any way relates to Unni, he speaks very frankly to Arjun Singh: "At 17, I too was in a certain phase and I knew what someone like Unni was about. I was a silent, removed, isolated person, wandering in the night for hours; I was comfortable with myself. Ultimately boredom plays a big part too. Strip away everything and it's just boredom. And especially when you're young and growing up in Madras " .[67]

Generally playful, on occasion he would escalate incidents -- arguably dangerously so, and occasionally certainly morally dubiously so (though Unni clearly had a strong sense of justice and what is 'right'). Ousep is correct in sensing that Unni's classmates were hiding things from him, and only slowly can he draw out a fuller picture of what Unni did and what he led them to do. For the major part, Unni seems like a great guy, as seen through the eyes of his classmates and the boys he used to hang around with. Halfway through the story, however, Balki, a genius and friend of Unni, reveals his memories of Unni and a distinctly darker picture of Unni emerges. A 15 -year-old boy who wandered the streets late at night to see the underbelly of Madras, sometimes returning home only at dawn. A mere boy of 15 . The age of innocence and of knowing. 
The age of coming to know.It gives one an unsettled feeling, as layers emerge to reveal facets of Unni that might not seem so appealing in broad daylight and to people of a middle-class mindset.

Unni also had an unusual philosophy: according to him everybody is happy. And people who are unhappy are only fooling themselves. The Chacko household, often wallowing in misery exacerbated by failure and impecuniousness, would suggest happiness is rather more distant for some, yet Unni seemed to live unencumbered by so much that weighs others down.

Finally Unni took a nosedive off the roof of their building without leaving a note or telling anyone close to him about the reasons behind his intentions to take his own life.A reason for Unni's action partly lies in one of Joseph's imperative in writing the book :" I want to explain time and again the sweet melancholy of pointlessness" .[68] Joseph was fascinated by is the pointlessness of everything. "I feel life is pointless and, by that logic, the novel is too. People often hold on to one thing, hoping it is precious, but there are those among us who can see pointlessness very clearly... To me, the shell and the message are equally important. And I wanted to tell this story by taking characters through the process of investigation and resolution... But the starting point was my interest in the humour and the melancholy of pointlessness." [69] The Illicit is weighed down by this oppressive hopelessness of existence in pre-liberalization India

\subsubsection{Ousep Chacko}

Ousep Chacko is Unni's father who carries the story along although he is a flawed and disturbed character. He is a fallen-from-grace journalist by day and an alcoholic neighbourhood menace by night. He is a wonderfully comic creation of the Malayali male, flapping his knees rhythmically while trying to understand what propelled Unni into a Byzantine tryst with fate.

$\mathrm{He}$ is one of the principal characters of the novel, a non-hero "who lacks noble qualities and whose experiences are without tragic dignity"[70] and who is " given the vocation of failure" [71] a person who is unlucky, clumsy and buffoonish. Being a loser in his struggle against adverse circumstances, he becomes an example of antiheroic ordinariness and inadequacy. Yet he is very much endearing to readers.

He was once a promising popular journalist in Kerala, but along the way he over reached himself. He was forced to migrate to Chennai after he broke the story of how a powerful archbishop in Kerala was a paedophile. When he was young everyone thought that he would one day be known as the greatest writer of Kerala. But then the years passed and somehow he did not write his great novel. "He decayed in a state of gentle happiness"[72] And as his career went into free fall, he found peace looking at the world through the bottom of a beer glass.

In the mornings Ousep looks exactly like the "Great Ousep Chacko of his mother's fables" [73] but in the evenings he is seen as a drunken man swaying unsteadily with his shirt dirty and wet, and trousers hanging. "Ousep is too strong, too clever, a solitary man. But when night falls he belongs to all men." [74] Despite the shame of the previous night, he walks from home each morning, " as if he is going to collect a lifetime achievement award from the president". [75]

$\mathrm{He}$ is portrayed as a somewhat failed and drunken journalist, who sets about trying to unravel the mystery behind 'why Unni killed himself. The novel is all about his gradual discovery of who Unni really was, what consumed his thoughts, what company he kept and how he came to end his life. It is quite surprising why Ousep, who otherwise seems like an uncaring father and a drunk apathetic husband, is obsessively looking for the apparently philosophical reason for Unni's Suicide.

People in the colony including Mariamma compares Ousep with "... with other men, the good husbands and the good fathers, their black shoes polished..." [76] However, he is not interested in "the other men". They never greet Ousep. Considering all that has passed and the way he is, people stare at him and he hates it. He is a man who "wants to be inconspicuous, who suffers when eyes are on him" [77] " There is usually a disjunction between the perceptual, outside world without and the spirit within"[78]

As the plot progresses the readers see in Ousep "a man illuminated by failure, a tragic father who is probing the life of his son". [79] Ousep knows that it is futile to probe into the reason for his son's death because "every suicide remains a mystery for ever" [80] for the fact that the only person who knows all the fragments of the motive is dead.

Ousep's drunken fits are eerily reminiscent of Salman Rushdie's description of his father Anis in Joseph Anton. [81] where he gives us a moving account of his complicated relationship with his father, Anis who bequeathed to him "an apparently fearless skepticism." His drunken entry into his apartment every night makes even the anxious Mariamma laugh. Yet his deep voice that "rips through the sullen calm" [82] reveals its tremendous strength in his unpremeditated thoughts that gets articulated clearly: "In your conjugal beds, you sleep. There you commit unspeakable acts. Comical acts. Failed acts. Man does many things with wife as witness. The stories that must not be told. Despite everything, man is safest beside his wife... Never stray too far from home, my friends... Great dangers lurk in the paths of men who live like men" [83] 
Ousep knows how cruel for Thoma to be in darned shirt and born-again shorts and rubber slippers held together by safety pins. He knows the impact of 'night of shame' on Thoma when Ousep stands 'almost naked in front of all, drunk and loud and pathetic' [84] every night. But Ousep also knows that ' he is what he is, he cannot be a better person'[85] Still he wants Thoma to accept the inevitable truth that an alcoholic father can give precious gift which is that he will 'never ever be a drunkard'. [86] "The happiest men in the world", according to Ousep,"are men who swore that they would never become their fathers" [87]

Ousep's search for the mystery of Unni's death brought many other revelations that compliment the primary objective. Unlike in novels and films, where witnesses being questioned always reveal valuable information that serves to lift the curtain on a secret, here the many people that Ousep interviews only remember random bits of information that are trivial in themselves and serve no purpose when considered as a whole.As Ousep's investigation goes on, it becomes clear that the Chackos are no longer a welcome part of the housing complex in which they reside. The father's drunkenness, the mother's insanity and the family's poverty have done it. And then Unni's suicide.

When Ousep set out to find an explanation for Unni's death, through the memories of people who knew the boy, he discovered a son whom he had not imagined." Unni Chacko who appeared to possess a superior detachment, apparently also had an unnatural curiosity about the world around him, as if he could see something extraordinary hiding in plain sight". ([88] Ousep realised, Unni was never the sort that could be swept under the rug. The people who knew Unni remember him in different ways that don't always unite. Some recall his brooding quiet; some his flamboyant personality. But in everyone's memory, Unni is a beautiful boy who affected them; and almost anyone who came upon him seems to have been utterly smitten with him in their own, peculiar, often inexplicable ways. People generally resolve suicides 'by considering it a consequence of unbearable grief or by manufacturing motives. Or through the inordinate importance given to the final note of the dead. So they would claim he had dark thoughts, that he spoke a lot about death or that he went to the funerals of people he did not know to see the faces of the newly dead in order to draw their portraits. Some say that he had a deep secret grief, of which he showed no signs. Ousep himself pays so much significance to "one inexplicable comic" [89] which has hidden inside the radio because it was the last comic series which Unni made before his death.

But as Ousep's persistence soon uncovers much of Unni, through the opinions of Sai Sankaran, Unni's fellow cartoonists, Beta, Illango, nun at St. Teresas's convent, Mythili, Balki and others. There is the creation of too much knowledge through permutations and combinations and figure that finally emerges out of all these is too complex to draw a simple reason for what he did. At the end of the novel " Ousep is too stunned to speak, he just sits there without a word"[90]. His search for truth is like the alcohol that drugs him and the book ends with a couple of statements: " Ousep, finally, in search for meaning. Resolute, even though he does not see Unni Chacko in another place, arching his body and laughing". [91] The way the author has characterized Ousep Chacko -the duality, the paradox and the contradiction in his character - is interesting. The way he treats his family, his neglect of the living for the dead is frustrating, but his persistent quest in knowing his dead son better and the thoughts he expresses in his moments of weakness also redeem him in a way and add a certain kind of poignancy to his character.

\subsubsection{Thoma}

He is the other son of Ousep who has never shown any of the promise of Unni. He tries to improve his mind but hardly possesses the power of concentration. He tries to memorize interesting facts but his head is porous. "There are only two impressive facts he knows... the full form of KGB, which is Komitet Gosudarstvennoi Bezopasnosti, and Pele's real name, which is Edson Arantes do Nascimento". [92] He hopes to impress Mythili Balasubramanium with this, if one day she would ask him these. He knows that miracles do not happen in his life. The thought of his bleak future brings the apparition of a woman with black decaying teeth who would be his future wife, "a fate foretold to all the boys who are not very clever". [93] He was constantly beset by doubt if he was handsome. His frustrated attempts to talk to Mythili left him feeling very low, "as low as a dachshund's balls" [94] Unni used to tell Thoma, mimicking their sports coach, " Fight, Thoma, put fight". He liked this because 'it says what he must do but does not mention the outcome at all." [95]

Thoma felt an air of triumph in his chest when he managed to divert the attention of his mother as she does the self- talking in the kitchen by mimicking her actions and inducing her shake with laughter. This was something only Unni could do when he was alive.

Thoma spends much of his time in daydreaming. It pleased him that Mythili was forced to obey rules in her house. "He imagines giving instruction to her and she meekly obeying". [96] Again, "Thoma imagines a day many years in future when he would arrive in a black car so broad that it would have to be parked outside Block A, and all the people of the building would assemble on their balconies to take a look at the car". [97] He would emerge from the car wearing dark glasses, white shirt, white trousers and pointed white shoes gleaming in the sun. 
Yet there are times when he almost decides to face the world and fight his way out for a respectable future. Ousep saw Thoma with his fists clenched and staring fiercely at the door. He was mustering courage to open it and go out. Ousep thinks that Thoma will create the world of "alpha males" - "a world where there is no place for drunkards and others like them. And the wild among men will have to seek refuge in failure to remain truly free." [98]

Thoma Chacko, is presented as just querulously stepping into adolescence, who is frightened of just about everything - his alcoholic father, his ardent mother, his beautiful neighbour, his unknowable future. He is scared of almost everything in life- torn between the fear in his own home and the fear and humiliation that awaits him outside his front door. It is in Thoma's wide-eyed remembrances that Unni is best delineated and, in fact, most missed. Thoma's small world lodges the stormy malcontent of middle-class drudgery and underachievement, impaled into luminous narratives that at once form the saddest and funniest parts of this discerning book.

\subsubsection{Mariamma}

The mother, Mariamma Chacko is a colourful character. She is indeed the Rock that stands true, eroded by so many tragedies. She is the marvellous Bertha Mason of the story - brilliant, delightful, wicked, tragic, and endlessly plotting the demise of her husband. Mariamma is so markedly intelligent and so sharp sometimes that the other characters seem ever poised to cut themselves on her wit. She is portrayed with care and love as a fascinating and troubled personality, a middle-class housewife of Madras in the 80s, who constantly lets out her frustrations by talking and gesticulating to the kitchen wall. Being alone in the kitchen she would wag her index finger at the overhead cupboard and would act out a dream log on Ousep or Annamol Chacko, Ousep's mother or Philipose. She reverts to fantasy as a method of trying to cover the bitter truth of betrayal from herself. The conflict that arises between pain and pleasure, between self and reality, between power and love receives full recognition in her solitary talk to the walls. . When she isn't cutting up her husband's clothing and fantasizing about his death, she tries refurbishing curtains into clothing.

She has much baggage from her childhood in Kerala. When Mariamma was twelve, she was molested by a local lad, Philipose. Later in the novel she is the long-suffering wife of Ousep and a loving mother. Her day with Ousep begins thus: " He does not ask for coffee, but she brings it anyway, landing the glass on the wooden desk with minor violence to remind him of last night's disgrace. She flings open the windows, empties his ashtray and arranges for newspapers on the table. And when he finally leaves for work without a word, she stands in the hall and watches him go down the stairs." [99]

Mariamma has to put up with Ouseph's drunken displays of self pity and aggression, which includes the neighbours and then suffer the ignominy of those actions from the same neighbours. She also has no money as he drinks it all and has to make do and mend whilst inventing new excuses for not paying the land lord and making underwear out of old curtains. She stretches the little money they get, raises their two boys. Sometimes she sells things in the house to get provisions for the house. Thomma was upset when he was told by Mariamma that she sold the sunglasses. "How can you o something like that, how can you take something from our house and go and sell it?' " I've done that all my life, you know that. All my gold bangles, they have become your shit, haven't they?" [100]

In her spare time, she gleefully fantasizes about Ousep dying. 'She would return from church on a quiet Sunday, and she would ring the door bell and he would not answer. And the door would be broken down, without much damage hopefully, if it were broken along the lock. She imagines Ousep dead, lying on the floor, his eyes wide open. She remembers the advertisement for a sunflower cooking oil - " A Gentleman's Cholesterol is in the hands of his Wife". [101] But soon she realises that Ousep is a man made of red earth and Malabar who cannot be killed by oil. So she walks to the bedroom and sits on his chair. she feels the strain of her body on its legs. Though she has to be patient, this is her only hope.

In the church, she is a devout catholic. In her spare time, she functions as the spy of the parish priest who brings him news about Catholic prisoners who are increasingly flocking to Pentecost evangelists. This she does out of her own misery, "because the priest waives the school fees, instructs the Sacred Heart Family Store to give her anything she wants on credit". [102]

She tried to transfer to Unni the etiquette of decent upbringing particularly in the way he should behave with girls: 'She used to tell almost every day how big boys should behave with girls. Boys must not harass girls, must not pass indecent remarks, must not stand too close to girls to even little girls, must not touch them'[103] After Unni's sad demise everything reminds her of Unni and has a haunting presence in her memories. She felt "there was so much peace in her boy" [104] Mariamma fears that the boy must have explained the reason for his action on a piece of paper which might have got blown away.

Mariamma was not part of the 'sisterhood' of the area." She is only a subject of their compassion, which is a cowardly form of self-congratulation." [105] They pity her for her poverty, for her man, for the loss of her 
child, for the way she talks to herself as she walks along the road and so on. All this to assure themselves that they are unlike her.

Mariamma turns anti-chauvinistic when she for a while how she could kill Ousep. "She could pour kerosene on him and burn him up. Men burn their wives all the time and get away with it... Burning girls, this country is full of burning girls, full of accidents in the kitchen. It is time a man went this way." [106]

Mariamma has a way for punishing Ousep for his irresponsible drunken routines. She throws a bucket of water occasionally on to Ousep when he does not wake up in the morning. And as she does that she would scream in evangelical shiver, " Reform this drunkard, my Lord, my God, he is the lost sheep, and you are the shepherd". [107] Sometimes she would wait for him to wake up "to scare him with a sudden howl' [108]

Equally, Joseph's portrait of the evangelical Mariamma is a tender tribute to the Jewish Mom, Kerala Chapter. She nurtures a secret, too dire to reveal, from her girlhood growing up in the rubber tree-filled estates of Kottayam. Despite the somewhat contrived nod in the direction of the Hitchcock thriller Psycho in the latter part of the story, Mariamma herself is an exuberant creation. There's a marvelous scene where she faces down a Pathan, who has come to demand his dues, with a broomstick. The author was very confident in the delineation of the charcter as he admits to Singh in an interview that " Mariamma is someone I know very well; someone I know for decades. In fact I had to make her milder, just to be credible." [109]

\subsubsection{Mythili}

Joseph speaks about the process behind woman characters:" I'm generally more fond of and curious about women. They are infuriating at times and I don't like a lot of things about them, but I'm very curious about them. It's a tough process though. The character of Mythili would have been more fleshed out if I had been a woman, but I couldn't get enough material or insight into her." [110] Mythili Balasubramaniam is a girl living in the adjacent block of Ousep Chacko's house. She is a thirteen -year old girl the only child of a dumb father and a very conservative mother. Mythili spent a great part of her childhood in the Chacko's home. When Mythili was very small, she played and went about Mariamma's house as if she was part of it. "... she liked Mariamma more than more than her own mother". [111] "She has eaten with Unni and Thoma, she has slept there some nights, brushed her teeth with the boys" . [112] She was very fond of Unni. 'They have walked holding hands, they have walked with Unni's hands on her shoulder, he has carried her in his arms and run the entire stretch of road.." [113]

When she grew up to be a young girl, she was forced to avoid the Chacko's. Her mother told her, "You can't go to that boy's house anymore. And I don't want him coming here. People have started talking... You are not a little girl anymore, Mythili." [114] To her mother Unni was "a mountain of a boy" and "Mythili had newly arrived, as a thirteen-year-old, to the outer edges of womanhood". [115] But Mythili fought everyday with her mother to retain her right to the Chacko's home. After Unni's death,"at the heart of her memory of Unni is the stillness of time - he is always seventeen, she is always thirteen". [116] When she saw Unni lying in a pool of blood, she thought, "Unni, what an idiot you turned out to be". [117]

After his death she has aborted any contact with the Chacko's. She often appears on the balcony of her house to rustle her hair or to draw her eyes underling them with fat pencil. " Her balcony has become a shrine that pulls boys and men from faraway places. They come to strut up and down the lane for her ... The times she appears on the balcony, it is as if a circus bell has rung and the clowns below must now begin to perform". [118] The persona of Unni is beautifully developed through the recollections Mythili Balasubramaniam.

Towards the end of the book, we are told that Mythili was sorry that she had abandoned the Chackos. In fact, the day Unni died, Mariamma lost a son and a daughter. But then the daughter returns watch over her until the end of time.

\subsection{Structure}

This is an excellent tale that weaves seemingly unimportant details into a well-written plot after the reader had half forgotten about them. "Plot saves you in many ways," Joseph says. "It is a concrete thing; there is a reason why it exists." [119] It is tightly-crafted and intriguing in its premise with some twists and turns. It also holds up a light to modern India as it is set in Madras in the 1990's and finds it wanting in many respects especially the societal cruelties that are played out to unwritten rules which no-one ever deviates from.

The book adheres to and delights in traditional story-telling structure. "I'm a bit of a beginning, middle, and end kind of a guy when it comes to a story," Joseph says. "In my early 20s I hated the modern American short story because I just didn't get it." [120] But while Joseph embraces traditional plot structure, neither does he shun the unconventional. Whole pages of the book are dedicated to explaining the elaborate stories of Unni's lost cartoons. One such cartoon which finds a way into the novel is actually the first short story Joseph ever wrote. It, like the novel, ends with a twist. "I was 11 and at that time I used to write all my short stories as a poem, with rhyming words, so if the story flops, at least it would rhyme," Joseph says. [121] 
The story takes us through four different journeys, each mutually exclusive yet intertwined by fate. It is an attempt to paint for us four characters, each with their own numerous complexities. While the construct is remarkably simple, the author is a master at de-constructing the lives and personalities of nearly each character. These, along with his asides, homilies and reflection of life will unmake and remake them over and over again.

It is a journey through the minds of various individuals who remind reader of frailties, small successes, huge fears and will to always be 'happy' that concern people. The plot does not end with a believable enough reason for the question "why" that gets us going from page one. It seems odd that the end affirmed the popular vote that it was indeed a suicide, rather than end as a tribute to the cartoonist- as a simple accident, a laughable one, even. It would have been commendable that Unni got the last laugh even as his father kept digging for a reason. The way in which Unni's personality unfolds and develops through second-hand accounts is brilliant.

The reconciliation of the plot looks somehow forced as it didn't quite agree with the protagonist's stance. Bearing the stamp of reality, it is hard to imagine this story as having a beginning, a middle or an end. Characters casually walk across these pages like unimportant side-actors who must speak their lines and disappear. And above it all, the voice of the omniscient narrator, as he watches over and recounts the life and times of the Chackos with an eye that is at once indulgent and satiric.

Eventually, Ousep does discover the reason why his son decided to kill himself. But the resolution of the mystery doesn't come until the very end. A time, when we, like Ousep, are thoroughly exhausted by the dead ends that plague the investigation. We begin to feel for this alcoholic father and this crazy mother who resent the illicit happiness of other people. The end leaves you more than a little unsettled. The resolution of the question that has haunted Ousep brings closure, but not of the soothing kind. It almost makes the reader want to plod through the book again.

\subsection{Narrative Technique}

The author peels off numerous layers of the story in a manner that the reader keeps craving to know more than what is revealed to him. The narrative does not follow a linear style. So the readers zigzag their way through the lives of Ousep and Mariamma and reach the past and go back and forth time and again. The backgrounds of the grieving parents help us to understand why they have become the kind of people they are. The truncated biographies piled together may seem to promise nothing more than a cast of characters designed to be quirky combinations of bizarre traits. But Joseph fleshes out the narrative with a submerged tone maintained almost throughout the book, a technique emphasised by isolated dialogue and scattered aphoristic wisdom: "A scooter in Madras is a man's way of saying he will not return home drunk." [122] Joseph's writing gradually propels this narrative into a philosophical pot-boiler, as the reader parallels Ousep's attempts to get a clear answer from schoolchildren, a silent nun and a corpse.

He has a witty style, adding meticulously observed details that make it exceptionally interesting. The prose is exquisitely phrased without an excess of sentimentality. It is crystal clear, not a word out of place, not a thought forcefully brought in. In one of his interview with the cartoonists, Ouseph holds the thick bunch of papers in his hand and walks to Beta.

'What is your name ?' Ouseph asks

'Beta.'

'What's your real name?'

'What's real about a name?'

'Why are you not Alpha?'

' Because I am Beta.' [123]

His deft use of language, his astute observations, his wry, subtle humour, and his way of telling a story in a few sentences are features of his craftsmanship: "Somen's father is bare-chested, his mother is in a sari. Ousep can see their bellies. And their deep navels that gape at him as if they are the alert eyes of a long, indestructible tropical marriage." [124] The writer makes the reader laugh on one page, and then forces him or her to ponder eternal questions or gives the reader a poignant moment on the very next page. Fusing ribald farce with poignant drama, Joseph deftly rotates narrative points of view and embellishes each strand with vibrant dabs of local colour that help showcase India in all its sublime and absurd glory. Wild, irreverent and blackly comic dialogues between characters are interspersed in the course of narration

His writing is unsentimentally exquisite and most refreshing, shorn of all pretensions to literariness ; the prose is languid and unhurried, didactically relying on loose precepts and sweeping philosophies. Few writers can write stereotypes and mouldy generalizations with so fine a grasp or so sharp an eye as Joseph, and, therefore, few can be forgiven for them as easily as he can:

As things are, it does not take much to be a spectacle on this narrow tarred lane. It waits all day to be startled by the faintest hint of strangeness passing through. Such as a stray working woman in the revolutionary sleeveless blouse, who has the same aura here as a divorcee. A 
man with a ponytail. A north Indian girl in jeans so tight you can see daylight between her legs. It is as if such apparitions are a sign that the future, which has arrived in other places, is now prospecting the city. Here now is the final stand of an age, the last time one can profile a street in Madras and be correct. Men are managers, mothers are housewives. And all bras are white. [125]

Despite telling a disturbing story, the narrative maintains an ironic distance from the characters using a prose style that is clear, wry, dry and witty. One friend of Unni's is described: "Sai stands in his spineless way, young but antiquated, studious but not clever, a thick steel watch on his wrist, his oiled black hair combed in the good-boy hairstyle. He looks like the past of an old man." [126]

Early on in the novel, when word spreads around Block A that a local man has suddenly died, the air of quiet disruption is perfectly conveyed:

Several men are standing in the garden and talking among themselves with their arms folded. The signs are unmistakable but the women of Block A decide to ask what has happened anyway. They lean over the balcony railings, hold their chests to keep their saris from falling and whisper their queries. The men walk down the garden towards the common wall as if they are about to urinate, which is not beyond them. They look up and whisper to the women what has happened. And the chatter of women begins, which drives away the sparrows. [127]

As blazingly talented as Serious Men was in so many ways, it could not have done many of the things going on in even so brief a passage as this. The dead man was only forty-two ("It is somehow appropriate that the age of such a fine man must be an even number"), [128] and the shock of the discovery is reflected in the picture of those neighborhood men talking "with their arms folded" - a solemnity neatly deflated by the sly little slander that it was "not beyond" these same men to urinate on the garden wall. This is marvellously controlled prose

His mother (a challenging part Joseph writes very nearly to perfection) can't stop thinking about that day, even though thinking brings no understanding:

Some things that even good people did were beyond comprehension. That was the thought in her head when she rose that dawn. but how foolish she was to think that was sorrow. In a few hours she would know what grief really was. Unni would be dead, and the next day she would see him lowered into a hole. And watch without anger as two labourers chatted among themselves while they shoved fresh soil on his coffin. And she would walk back home feeling strangely empty-handed. That is what she remembers the most about the evening - the feeling that her hands were empty. [129]

Lots of people talk about Unni in the course of this moving, mordantly funny novel - he is the hole at the centre of the narrative, the absence that causes all the action we see. Madison Smartt Bell used a very similar structure in his great 1987 novel The Year of Silence, [130] although without daring to graft on quite so much dark humour. And Joseph saves the process from sentimentality by periodically skewing our picture of saintly young Unni. A brief scene at the book's mid-point, in which Unni leads his fellow St. Ignatius students in a savage assault on a sadistic instructor named Simion Clark, is riveting precisely because it's offered without apology. We finish the book overwhelmingly sorry for the forces that drove Unni to take his own life - but not entirely certain we would have liked him if he'd lived. At one point in his investigations, the hapless Ousep is told, "In a farcical world, farce in the true art." But the courage of The Illicit is precisely that its world is not simply farcical. There is an enormous fund of feeling running through these pages, turning one family's disastrous response to tragedy into something both personal and universal

Joseph is a great observer and here he captures the nuances that make us smile expansively. The scooter drivers sitting at the edge of the front seat, for example. His descriptions make us think of everyday things that we take for granted, stuff that does not merit any attention from our conscious minds. Ordinariness of life filled with pressure cooker whistles and school going children and husbands leaving for work every morning. Children memorizing their lessons. All staid and commonplace Joseph paints a vivid picture of the ordinariness of life, of the inevitable sameness of our behaviour, and how we treat death, others' deaths, others' sorrow as a spectacle. It is the turns of phrases that are the most interesting, that invite you to go back and read a sentence or a paragraph over and over again: 'The past of an old man.' 'The good boy hairstyle.' 'How strong the legs of dumb parents, how strong.'

Joseph's prose has an informality about it. He often begins sentences with "And", or use an extra word like "actually" to create a naturalistic, speech-like effect. These aren't things that are usually approved of in western models for literary fiction. In an interview he admits that it wasn't a conscious process:" I'm straightbatted in many ways; I like the beauty of the straight bat. Of course, I do like the Sehwag moments also that's one of the best things about art, how it can surprise you. I also use "also" very often. It's convenient also from a technical point of view - many of my paragraphs are really one sentence that has been broken up into many sentences. I don't like using semi-colons; I try to avoid them. I hate exclamation marks. In Open I've 
banned the exclamation mark. [131] He has also explored in the novel the ideas of the inadequacy of language, of the "austerity of human communication", of the feeling of being trapped in and by language. These are ideas which harp on the post-structuralist understanding of language. In a conversation with Gupta, he reveals " I have always been intrigued by the relationship between language and thought, and about how infants think, which they do in fact all the time. When I am fully confident of my skills as a novelist I may try a novel which is entirely told by an infant. In The Illicit Happiness of Other People, I wanted to ask, in passing, if language limits our thought, and if it does, why, and if as adults we have forgotten how to think without language". [132]

Joseph's eloquently-phrased novel takes the reader on a journey that parallels Ousep's attempts to gain a clear understanding of Unni's death. It's witty, endearing, and intelligent All the skills so prominently displayed in that first book - canny descriptions, scalpel-sharp character descriptions, most of all a positively vaudevillian comic sensibility - are evident again in The Illicit, but there's far more ambition, far more rumination, and far more depth. This is no longer the work of a precocious new gate-crasher; this is the first product of a truly gifted new author. Both the content and writing style of The Illicit are reminiscent of many of the works of Haruki Murakami. Both combine quirky characters and situations, humour, mysteries, wild goose chases, and philosophical and psychological theories into entertaining, yet thought provoking, insightful novels.

\subsection{Humour}

The Illicit is appreciated by people who enjoy Joseph's signature wit, his cynical and acerbic jocularity and his love for the philosophical amidst the apparent humour. The author has no sympathy for the blinkers that old India clapped on itself, but even as his scathing critique stings painfully, Joseph's sense of humour makes it impossible for a reader not to grin while reading the novel. For example, how can the reader not nod in agreement to this:"What is this world, exactly? Thoma wonders. A man slaps a girl's arse, she walks on as if nothing has happened. Then the man gets hit by a coconut thrown by a weird woman, and he walks away without even turning back.". [133] Or for instance, during Ousep's conversation with Ilango, one of Unni's classmates, Ilango recalls what Unni told him about the most powerful booze in the world which he claims is found in Kerala. He said it is called Jesus Christ because"if you drink it you will rise only on the third day." [134]

One of Joseph's strengths is a knack for seeing the funny side of solemn situations. In one passage a woman comes home from shopping, looks through the door and sees her husband, who has died of a heart attack while she was away. And she tosses a brinjal at him to check if he is alive. He just slips that line in, and he doesn't make a big deal of it, but it is there all the same. Again, Ousep describes the first day of the 'fast-untodeath' [135] with the objective of forcing the government to initiate action to protect Tamils in Sri Lanka. These men were 'in starched white shirts stitched for the event and veshtis that are bunched in a way that magnifies their groins. There is a long silver torch beside every fasting man. The reporters know that the torches contain stuffed bananas instead of batteries, which will be consumed when the martyrs go to urinate".[136] It is on the one hand a serious book, but also a book laced with black humour and keen observations on human nature . Ousep gets back home drunk every evening while 'the other men', mostly bank clerks, return home on their scooters at six in the evening carrying jasmine flowers for their wives. Hard-news reporters like Ousep consider it an insult to be seen on scooters. " A scooter in Madras is a man's promise that he will not return home drunk in the evening." [137] When Unni was a little boy he was deeply interested in getting married. He was just five then and he was willing to wait till he reached the legal age but not day more. He was so desperate to be married that she ( Mariamma) often used it to get her way. " Unni, if you don't brush your teeth I won't get you married' That was enough to send him to the bathroom." [138]

It uses humour to deconstruct and satirize even its own assumptions. Thoma being quite weak in maths, Unni tried to assure him the "home minister, who is responsible for happy homes, would soon pass a law changing the value of pi from 3.14159 to just 3, making it easier for all Indian children to calculate the area of a circle." [139] Thoma has learned to memorize the full form of KGB and Pele's real name. He longs to impress Mythili Balasubramanium if by miracle she would ask him these. " But miracles do not happen in Thoma's life, even though he is a Christian". [140]

That there should be comic sensibility at all in this book is remarkable, considering the immutable sadness at the heart of the plot. That sadness has a name: Unni Chacko, "handsome in a careless way, passing through life with the lethargy of an artist," the sweet, artistic oldest son of the Chacko family, the pride of his father Ousep, a sentimental and hard-drinking journalist, and his mother Mariamma, who has long been convinced of Unni's special ethereality. The book injects dark, rueful laughter into an immensely touching story of loss. It is the seamless infusion of humour with tragedy makes the book a joy to read.

When Unni calls Thoma a 'mutant',( "A mutant has abilities other humans do not have" [141] ) Thoma felt happy and began sharing his peculiar sentiments. He tells him that when he feels sad, when he thinks of the way their mother talks to herself, how their father comes home drunk, how they never go out as a family because they did not have money, when he thinks of all that he feels a sorrow in his throat which becomes a 
ball. He tells Unni he really enjoys the pain in his throat and the way tears flow from his eyes. Later Unni shows the name of this sentiment as 'Self- pity" from the dictionary which he says is Thoma's contribution.

Ousep tells Mariamma, "The secret of happiness is not to have any expectations from people". [142] After the tragi-comic nights, mariamma wakes up early in the morning "to the fragrance paradisiacal breakfasts and the long whistles of steam from the kitchens of happy people." [143] When Unni was dead, Mariamma waited in an impossible hope for a peel of laughter: '...the three of them had stared at Unni's body when it lay in the hall under a white shroud... in a deep hopeful silence, and waited for him to wake up any moment and burst out laughing'. [144] In Ousep Chacko's house, "the life of Colgate is squeezed out of it until it is a flat strip of thin tortured metal", the toothbrushes are not thrown away until all the bristles disappear, "soaps are used until they go missing in the crevices of the body", "the empty oil bottle is left standing inverted on a frying pan" for the last drop and the foam sofa in the hall shrouded by an old bed sheet has a giant secret hole in the centre in which a few serious visitors were trapped. These made Ousep and Mariamma laugh, " their laughter rising in pitch in competition, neither willing to stop and grant victory to the other." [145]

Joseph admits in an interview "I like the juxtaposition of humour and tragedy. You see more of it in movies; in the Coen Brothers' A Serious Man, for example. I'm always fascinated by why people laugh when there is turbulence in a plane and you fear you're going to crash. ...it's such a serious thing: laughing." [146] Perhaps what keeps Joseph's work enjoyable and fresh within such a deep, intellectual tone are the wit and tender emotions weaved into such heaviness that it helps to lighten the load.

One important thing the author believes about humour is that "at its core is accuracy". When one is extremely accurate about something, it becomes funny. [147] "Humour assaults us with a slice of truth." Joseph says in The Illicit. There is also a mention in that passage of the evolutionary origin of laughter; it came from a ferocious face that early man made when he wasn't sure that a danger had passed. "I think the most underrated humour writer in the world is J.M. Coetzee; his eye is so uncompromising, his observations are so exact. " [148] The novel like the absent protagonist, Unni, cut through the clutter and see the essence of a person or a situation and this creates humour.

Also notable is the author's use of sharply humorous analogies. This is the sort of thing that can get tediously overdone in writing, but he does it so well that it gives the reader a fresh, clear-sighted way of looking at something. For instance, two girls at a cartoonists' meeting survey the others with the amused look of the newsreader who has just got the "serious" political news out of the way and is about to announce that a zoo lioness has delivered four cubs. It creates a mental picture immediately and one understands something about these characters and how they fit in with their surroundings.

\subsection{Parody}

Ever since Cervantes brought Quixote to literary life, the western novel has subjected idealistic metanarratives to parody. In the novel, the two principal characters, Ousep and Unni, reveal a parody of what Joseph Campbell demonstrated as the three stages in the universal path of a hero against time and culture: a. Initiation into the unknown, b. Encounter with hardship, rise, failure, loss and discovery, c. Return into the fold with something new [149] Unni always sought to get initiated into the strange, out-of-the-ordinary and the mysterious. His encounter with the nun, his confrontation with the teacher, his attempts to understand death by gazing at the faces of the dead, his encounter with women and so on do show how keen he was to get initiated into the unknown. Similarly Ousep gets initiated into mystery of Unni's death through the cartoons unni has drawn. The self imposed tasks that Unni and Ousep engage in and finally ruin the task by not succeeding in their objectives. Once others comes to know the task that Ousep in his ceaseless search and Unni in his exploration of existential fulfilment both of freedom and self- definition human nature undertake, they are burdened by expectations of people upon them. The guilt and the realisation of his self-delusion finally lead him to desperation. Ousep is more like an anti-picaroon who undergoes several mollifying experiences but hardly discovers his true nature. Like the heroes of Stendhal, Balzac, and Flaubert, Joseph's principal characters are protagonists of ironies, whose ideals of desires and feelings are in disharmony with the common conception of reality.

Joseph's principal characters becomes one of us - homme moyen sensul. The traits these exhibit are spiritual aridity, mundane lives, failure, attraction towards evil and chaos. No one can for sure define what Unni or Ousep clearly stands for. They are victims of angst, suffering from dread and anxiety, who encounter the void and often fails to find justification for the choices they make. Ousep's capacity for pain seems saintly but his passion for heresy becomes almost criminal. Yet flowed in his sainthood and grotesque in his criminality, he appears as an expression of man's quenchless desire to affirm, the deep and disquieting insights on the human sense of life despite the void and vicissitudes they encounter. Ousep's or Unni's quest for truth is a quest for a Godot. Thus like the major writers of the 20th century, Kafka, Sartre, Camus, Camus, Beckett et al, the principal characters of Joseph struggle with the cardinal question concerning the ontological problem of man's being - the encounter with nothingness. In this encounter, they suffer from a split in their personalities. Their inability to 
mediate between the external society and the internal world and between the outer and the inner real self leads to the splitting of their personalities. They have a fragmented mind and body, with the two divisions moving in the opposite directions.

In a situation where life is meaningless and anxiety the only reasonable mood, the option left before the characters is either just to go on till they collapse or to end the force of circumstances by confronting death or nullify their identity in search of anonymity and solitude. They come to understand all truths are personal truths one experiences in anguish, pain and action.

In Ousep's encounter with absurdity, with death, with chaotic anarchy and nothingness, lands him in a predicament of making an affirmation. This he postpones by a never-ending search for the mystery of Unni. Joseph Conrad envisioned the fate of man as a solitary being who must suffer and endure his trials and tribulations alone. The only way to compromise with this absurd situation is to submit oneself to the chaos." A man that is born falls into a dream like a man falls into a sea. If he tries to climb out into the air as inexperienced people often endeavour to do so he drowns. The only way is to the destructive element submit yourself." [150] This submission to the destructive element is true in the case of Unni, a representative of contemporary protagonist-man. The unintelligible / unintelligent brutality of existence leaves man with no choice. Ousep submits to the incomprehensible chaos of information on Unni available around him which he tries to gather. Every attempt to understand this chaos results in further confusion

Unni moves about like a fish bound to be baited one day. The freedom enjoyed by the victim is just an illusion making his fate cheerless. He fulfils his destiny by mediating between the contradictions to which we are heir, and by mediating between them in the process of his initiation, his discovery, which often leads him to the brink of defeat.

Unni is a mythic figure without the benefit of a myth. In him the essence of the world and the essence of the self are not one and the same; the broken pattern of all his action recalls the futile courage of Sisyphus toiling to unite one pole of experience with the other. He is now the mediator of forces that torment his existence. If mythic feature is exhibited in the sacrificial quality of his passion, his actions have the concrete self-definition of an existential encounter.

His pride makes him reject the very thought of submission. He has the awareness that he is an isolated being, cast into an alien universe which possesses no inherent truth, value or meaning. His life thus moving from nothingness to void defines an existence which comes across as both anguished and absurd. It is the anguish of the one who has the foreknowledge that all his actions will be meaningless yet he has to act. Ousep was cursed to wander the ends of his world without finding solace for his anguish. He is an ordinary man beaten and bogged down by the sheer weight of life - its repetitions and darkness, and its meaninglessness.

Manu Joseph's characters does not belong to the high -mimetic mode protagonists but to the low, abounding in irony and contradictions. For Nietzsche, Dostoevsky, and Beckett, a man is but a pawn in the hands of unknown forces. Hence the protagonists reject the concept of task, journey and quest. But Manu Joseph's principal characters though non-heroes engage in task, journey and quest. In the postmodern world of exhaustion where these are peopled, they are schlemiels, ironic anti-heroes who are apt representatives of the society of failures. In a world where success is measured only in terms of external affluence, these exist in static state, either unwilling to move ahead or wreaking chaos around themselves. Ousep, rather than being the centre of Chacko's family binding its members in affective bond, he becomes a victim of alienation, cultural and spiritual sterility, seeking solace and refuge in alcohol, self-deception, power, social withdrawal and anonymity.

There are also a number of instances that parody catholic practices. Thoma was watching some eight girls of his age sitting on a wall and chatting. Padmini, in a rare careless moment, spreads her legs and exposes her underwear which is seen by Thoma. He was unable to look away even though he was aware he was involved in an act of gaze. Then Thoma feels the need to confess this to his mother. He chooses the time when she was doing the dishes in the kitchen. He stands near the stove and numbs her mind by mumbling many things and finally arriving at a prayer: "Our father in heaven, hallowed be thy name, I saw Padmini's undies. Your kingdom come, your will be done, on earth as it is in heaven". [151] This parodies the various stages of confession in catholic churches.

During the funeral ceremony of Unni, the priest comes to the altar and utters a senseless sermon to an empty church throwing glances at the walls and the floor and the empty pews. The narrator sums up his words thus: " The story of Unni Chacko's life as told by an imbacile to an empty hall". [152] Then for a moment his eyes rested on Mariamma and stayed longer than he had intended. Soon his face changed from blank to disturbed and he began to prey in a distracted way. The priest here does the ceremonies like many of the automated actives that fills his day.

Ousep narrates the past of a nun in St. Theresa's Convent. He remembers her a sleepy girl with eight younger sisters who used to walk behind their mother like piglets passing by his house. When she grew up into a young girl, she was among those who stood at the bus stop giggling at the bus conductors who had fair skin. 
Then one day her father decided to make her a nun to save her from poverty. After she was sent to convent, she ran back home twice. But the third time she was deposited in the convent, she accepted her fate.

The rosary moves between Mariamma's fingers, but her lips mumble other things as she waits for Ousep to come home at night. And when she knows he is somewhere near the gate, " she clenches her fists and mumbles a Hail Mary" [153]

\subsection{Satire}

There is a constant conflict between Joseph the story-teller and Joseph the satirist. At times Joseph the satirist gets carried away and one starts wondering where the story has disappeared to when Joseph the storyteller makes his appearance. In any event, Joseph's trademark satire is reasonably entertaining and Joseph the story-teller holds the reader's attention till the end.

His novels at its best have no competition in making sense of our world--which seems so complicated, but is still driven by the same fundamental delusions novelists have been exposing since Cervantes and Swift. Satire seems to be undergoing an incredible worldwide renaissance. The Bush years helped it along in America. In rising countries like India, it seems like a very suitable form of expression. Perhaps one will see an outburst in Russia too. One thinks of Mohammed Hanif's A Case of Exploding Mangoes as a parallel novel that mocks absurdity. But Joseph feels that a person cannot sit down to write a satire. Satire is the analysis of the reader, probably even the creation of the book reviewer. Satire is not a conscious process of a writer, it is the reaction of the reader. Satire, Joseph claims, cannot and will never be a trend.

There is much delightful satire in Joseph's descriptions of life in 1990 Madras, a city that is as much a character in the book as Mariamma or Ousep. These standalone satirical passages are perhaps the biggest strength of the book. The imaginative descriptions of Unni's cartoons, that almost makes you feel you have seen them all yourself, give the book more weight than the actual story.

Joseph discloses in the Acknowledgements section that he spent the first twenty years of his life in Chennai. We know that Joseph was born in 1974, and so it looks as if Joseph lived in Chennai during the period the story is set. Making a comment on the people living on the narrow tarred Balaji lane there, he says," Here now is the final stand of an age, the last time one can profile a street in Madras and be correct. Men are managers, mothers are house-wives. And all bras are white. Anglo-Indian girls who walk in floral frocks are Maria". [154] Later speaking on the exceptional fears of the adolescent boys on Balaji Lane, the narrator has a few interesting lines: " They are terrified of everything, of life, of their future, of friends doing better than them of falling off their cycles, of big trucks and large men and of beautiful women. The only thing that does not scare them is calculus... The day they were born and were diagnosed with having penis, their fate was decided to one day to take joint Entrance Exam". [155] Therefore, it is unsurprising that Joseph manages to convey the feel of 1980s Chennai, with its street demonstrations and hunger strikes in support of the Sri Lankan Tamil cause, to the reader.

Unni's comics titled "Absolute Truth", "Enlightenment", and' 'Beatles Crossing" have the force of Swiftian satire:

In the comic ... Absolute Truth, a blank white envelope floats through the deep space, orbits strange worlds and finally heads towards Earth. When it enters the Earth's atmosphere, the envelope burns and what emerges is another white envelope. It has 'Absolute Truth' written on it. It floats down and falls on the endless field. A bare-chested farmer picks it up, opens the envelope, takes out a sheet of paper. He reads it and starts laughing uncontrollably. He passes it on to his wife who, too, begins to laugh. She shows it to the infant in her arm, who becomes breathless with laughter. The farmer passes the Absolute Truth to his neighbour, who holds his stomach, rolls about his cabbage farm and laughs. The letter changes hands across homes, villages, across cities, across the whole world, leaving people hysterical with laughter at the long awaited discovery of absolute truth. [156]

The author's illicit laughter of the socialists who according to him are noble conversationalists working hard to preserve poverty in the world is particularly striking :"And future generations will not know ... the true nature of poverty, which is the longest heritage of man. Shouldn't this be preserved somehow, like old colonial buildings, shouldn't abject poverty be preserved as historical evidence? That is what socialists are trying to do in the country". [157]

\subsection{Psychological Mystery}

Mystery novels, owing their existence in a large part to the deluge of 'Detective' stories that thrived primarily because they piqued reader's curiosities, have now run their course. A concept, an idea, a fundamental premise can only be replicated, albeit with necessary variations to keep intact a notion of originality, so man y times until the dam of creativity is breached. After this innovation picks itself up from the driver's seat and 
disappears into the cargo compartment of a dead vehicle. Simple yet engrossing plots, with requisite decoys, diversions, obscure hints, misled pursuits will at the end of the day bow down to the, now almost mechanical looking, revelatory whodunits in a master-swish of a vulgar display of remarkable deduction, grit and intelligence. And that too, in so formulaic a manner that most mystery novels just appear as intelligent pot-boiler masalas. The genre is not to be blamed, for it was its very popularity that led to the deluge of stories that diluted its appeal. Such stories are now in their terminal stages of existence. But, what if mystery story-telling is reinvented in so innovative and delectable a manner, that all its best aspects are retained, including a paced plot, without falling into any previously well-entrenched pigeonholes? That precisely is the remarkable achievement which 'The Illicit Happiness of Other People' by Manu Joseph is.

For those of a more postmodern persuasion, rest assured: any lack of ambiguity or complexity in the plot of The Illicit is more than made up for by its knotty philosophical content. Morality is not straightforward in the novel; nor is happiness. As the story unfolds, possible psychiatric explanations are put forth for some of Unni's more fantastic philosophical ideas-but Joseph remains a student more than a teacher, never revealing whether all of this philosophy could be dismissed with science, or vice versa.Ousep's search for answers takes him from the dreary routines of the daily life to philosophical, moral and psychological planes, creating a vast canvas. This is primarily a "mystery novel" well told through unforgettable characters. Indeed, there is much psychological mystery and the involved reader finds himself as baffled at Unni's actions as his father, the remarkable Ousep Chacko, banished journalist, failed writer and noisy drunk who has "gone too far the Malayalee way" [158]

The main characters are deep, intriguing and strong personalities, making the reader look forward to what they would do next. The novel is set in the southern Indian city of Madras in the 1990s and has splendidly funny, sharp and perceptive observations on the Tamil residents of Madras and their preoccupations.

Unni Chacko expressed his comprehension of the world and pursuit of truth through his cartoons. The novel is all about his gradual discovery of who Unni really was, what consumed his thoughts, what company he kept and how he came to end his life. The story follows Unni's brief life in search of what he believed to be the Ultimate Truth. We are taken through a maze of the many psychological posers that Unni and his buddy Somen Pillai create before arriving at the reason behind Unni's decision to commit suicide. The persona of Unni is beautifully developed through the recollections of his mother, his friends and the neighborhood girl, Mythili. The author seems to have done substantial research talking to neuro-scientists about the nature of mental disorders. One of the central themes running through the book is the possibility that the pursuit of Truth, in most cases, could be just a mental disorder and Enlightenment, just a schizophrenic condition!

How well do we really know the people closest to us and how can we qualify something we believe as being a factual truth when every individual has the ability to perceive the same event in a slightly different way? Joseph's novel takes a brilliant turn towards the philosophical in a quest to extrapolate greater universal understanding from the passing of a single child.

According to the Diagnostic and Statistical Manual of Mental Disorders [159]used by mental health professionals the world over, depression and delusion are both definable, treatable illnesses that seemingly any member of the population can become afflicted with. But doesn't the opposite have to also be true? Shouldn't a counter state of overwhelming happiness also exist? After all, how can one have bad without good or right without wrong? Why has no one dedicated the time and resources necessary to exploring the root cause of happiness in individuals?

That might sound silly at first, but when one stops to think about it, it becomes more likely that those who have a clear, unencumbered vision of life, and those that claim to be closest to understanding the secrets of the universe-the secrets of God himself-are the ones who are potentially the most damaged among us. Joseph in a conversation gives one of his recollections on the subject: "One of my friends didn't make it through. I learnt after I went to Mumbai that he jumped off the terrace. Everyone said he fell while trying to save a dog but I know he jumped because, years before, he had told me he would," says the author who maintains that though his friend was an undiagnosed bipolar personality he was "the most sane person I've ever known". [160]

While the traditional definitions of mental illness do play a rather large role in the novel, surprisingly they are not its focal point. What Joseph seems to want to state the case for here is the idea that a perfectly average, seemingly mentally unencumbered person is in fact just as ill. Is it such a stretch to imagine that most of population is suffering from the horrible effects of sanity? Does this sanity inhibit the majority from seeing greater truths that are lurking all around them? And what of language? Is it a woefully inadequate trapping devised solely to stop us from understanding the larger world around us? How, for example, do you describe the colour red to someone who has never seen it before? Just where do we turn when our comprehension exceeds our ability to explain?

There are also some profound statements about Life and Truth coming from Unni. For example, at one point, Unni elaborates his theory on how ordinary men manage to cast such a spell on women who are much cleverer than them. He says: " ...the fundamental quality of a delusion is that it is 
contagious. The very purpose of every delusion is to transmit itself to other brains. That is how a delusion survives. On the other hand, truth can never be transmitted. It does not travel from one brain to another. Movement is a quality of delusion alone...." Elsewhere, the neuroscientist Dr.Iyengar says, "....the society of neuroscientists would admit that all evidence points to the fact that God is a figment of man's delusion, yet believers in God, who form most of humanity, cannot be considered delusional. This is a ridiculous position..." [161]

\section{Thematic Features}

Joseph explores a mind-boggling number of themes such as adolescence, religion, homosexuality, science and politics. These themes are the outcome of the tender portrayal of the anxieties and ambitious of Indian youths and the parents that watch them struggle with social pressures as they come of age as adolescents and young adults. All the characters look at life through Unni. And the ideas that the author throws around are amazing: schizophrenia, good vs. evil, the complexity of self-perception amid present-day life, the great philosophical questions of happiness and life, family relationships and ultimate mysteries, revenge, shame, guilt, and every similar human emotion is tackled at least once. If there are any other botheration of the modern-day man, the author included them all in the book. It is exactly this heterogeneity of these topics which makes the book likeable and dislikeable.

Joseph writes with extraordinary wit, cunning and sympathy about both - the questions it explores. Questions about connections between perception, philosophical quest for meaning and what is known as psychological disorder. How much imaginativeness and quest for knowing what is beyond our immediate existence is normal? Could it be that people with so called psychological disorders actually have enhanced senses and perceive what is beyond the "normal"? Does a person with malfunctioning senses perceive the world and its meaning is a different way altogether? Is there a concept of absolute sanity or is it merely defined as the level of thought and understanding possessed by the multitude?

\subsection{Inversion of Conventional Thoughts}

The Illicit is a novel that makes the reader laugh and think, a novel that explores human emotions and the paradoxes within them without any of the melodrama that one might abhor and detest, a novel that will constantly coax its readers to understand the world from a perspective different than the usual.

Joseph's novel centres around a group of adolescent boys living in the 1980s in Madras asking one another dangerous, if standard, philosophical questions: Is this reality the only reality? Is happiness nothing more than a shared delusion? Do we pursue happiness or does it pursue us? This feature of the novel, Joseph says, is only fiction "in the legal sense." "When I was an adolescent and growing up in Madras, I was part of a group which got sucked into philosophy in the sense that we were always very sure that something was going on," Joseph says. "And this was before The Matrix." [162] Worried that life as we know it may be nothing more than "some kind of bad movie," Joseph and his friends questioned everything. Years later, he says, he still isn't certain of the answer.

The novel is an admirable blend of plot and ideas, of a story that reads like a mystery but also of the kind of philosophical and social observations that are inversions of conventional thinking. For instance, the book questions our idea of sanity and argues that sanity is a majority psychiatric condition, and that what we call ideology, even the idea of enlightenment, is probably a psychiatric condition." One of the book's themes is that we all talk about clarity and sanity all the time, but the truth is it's very dangerous. True clarity and sanity won't allow you to do anything - it will just make you jump off the building. The pursuit of truth itself is a psychiatric condition.." [163]. In this light, the novel raises questions regarding the many myths of sanity and the outer reaches of mental aspirations.

The narrator says that alcoholics have a lot of friends because "what men find most endearing in other men are their tragic flaws; Unni's theory that the unfortunate are not as miserable as the world imagines; that " the wild among men will have to seek refuge in failure to remain truly free.' [164] ;; that "Drunkards do live long. They are careful people, especially when they walk on the road. No man has a greater purpose than a drunkard" [165]; and so on are thoughts that keep the careful reader pose for a while before proceeding.

Joseph's thoughts on 'happiness' gets a special treatment in the novel. According to Unni, as reported by Ilango, "everybody is happy. And people who are unhappy are only fooling themselves' [166] This is Unni's hypothesis - the inevitability of happiness, the persistence of happiness. "Happiness is an inescapable fate, not pursuit." [167] and that "ambition is the capacity for unhappiness". [168] In an interview with the author, Netzer reports on his preoccupation with happiness : "I'm a very pleasant person. I rate myself as very happy." Then he adds that happiness may be a bit underrated."There are a lot of artists who have made a good living from melancholy. Their gift is that they're able to absorb a lot of shit and write about it—grim, dreary things. And I look at them with a lot of suspicion, and I try to understand, is there a literary value here or is it the value of 
sorrow?" Indeed, with Happiness, Joseph has made a convincing case for exploring the depths of joy the way so many of his predecessors have plunged into melancholy". [169]

The notion that evil prevails over good and the common belief that good is the absence of evil gets a different treatment in the novel. For instance, Beta, one of the cartoonists reveals to Ouseph that Unni was working on a graphic novel. Unni was trying to plot characters into an idea of how in the fight between evil and good ended with a "total, irrevocable extermination of good" [170]:

Thousands of years age o in the history of man, a great darkness has fallen. The war between good and evil has ended. And it has ended with the complete triumph of evil... Evil is cunning, it quickly splits itself into two - into apparent good and evil, so that mankind is under the delusion that the great conflict is still raging and it will not go in search of the truth. So all that we think is good', Beta says, 'love, and art and enlightenment, and all that we think is the pursuit of truth is actually a form of evil. [171]

This is quite unlike the structure of stories where good is given a chance to defeat in the end. Every storyteller used to work within this con. Everyone believes that things hidden will come to light and that a door will open to someone who knocks. The novel questions these taken- for- granted-truths and shows them quite murky. The author's notion of morality is also striking: "morality was probably the invention of unattractive men. Whom does it benefit really?" [172] Similarly also is the idea of resolution: "That a mystery must have a resolution is obviously not a requirement of nature. It is, in fact, another deceit of writers. a plot device, like the idea of a beginning, middle and an end. In a real world, are mysteries really solved?' [173] Again, if for a person there should be a reason to live and a reason to die, then 'shame' is reason enough for a person to die. Thoma states this pondering on the probable reason for Unni's death ." There cannot be better reason for a person to die than shame" . [174]

If it is a common belief that language aids expression, then Joseph has a long umpteen references on the inefficacy of language. Once Unni told Sai that " language was not the medium through which to understand things . " Language was created by nature to guard its secrets not to reveal them". [175] Earlier in the novel, the narrator says that " Language is a trap, that a dark evolutionary force has created language to limit human thought". [176] The narrator stresses the role of religion and comics to free humanity from the trap laid down by language: " That all religions came from ancient comic writers And that the ultimate goal of comics is same as the purpose of humanity - to break free from language". [177]

"According to novelist 'truth shows humanity in a poor light, and the misanthrope, alone, has a clear understanding of humanity. Fortunately or unfortunately, Joseph deems many of us misanthropic, referencing the misanthropy behind ideas and policies that govern human behaviour, namely the concepts of the city and population control." [178] Joseph explored these ideas and many other thought-provoking theories on human nature.

\subsection{Nihilism}

Ihab Hassan makes the following statement concerning the modern protagonists as the anti-hero in his Radical innocence [179] : 'The world at our times seems to have... become a rigid, intractable mass; and anarchy of nihilism and the terror of 'staticism' delimit the extremes between which there seems to be no viable means. Mediation between the world and the self appears no longer possible; there is only surrender and recoil. In his recoil, the hero has become the antihero." Manu Joseph's exposition of the tragicomic life of a unidimensional teenager (appropriately called Unni) is nihilistic in its approach, evidenced by the number of times that the words 'nothing' and 'empty' appear at regular intervals in the text. The three years following Unni's death is trapped in the irremediable routine. Neither ousep nor the people he encounters have any reliable elucidations to offer to the mystery of Unni's death. The truth becomes forever in the process of becoming, in the process of unending flux and Ousep refuses to admit he is a failure. So he must go on absurdly.

Besides, the basic premise of the novel itself is nihilistic : Unni's father, Ousep, who otherwise seems like an uncaring father and a drunk apathetic husband, is obsessively looking for the apparently philosophical reason Unni killed himself; Mariamma, Unni's apparently insane mother, whose unhappy childhood has led to an unhappy marriage and delusional children, drops obvious hints about her condition to the reader; and Thoma, the surviving sibling has recurring memories of the fateful day, and apparently suicidal tendencies of his own. Why apparently? Because nothing is as it seems and there is nothing unusual about the reason behind Unni's death in the end, except that it is silly and somewhat unbelievable.

Interspersed with neuropsychological conditions, adolescent sex, dry wit and sarcastic black humour, the book, written largely in the present continuous tense, walks the reader through the minds of the three characters, leading to the unravelling of the mystery of the teen comic writer's or Unni' suicide. One wonders about the what and the why of such a long drawn exercise, only to be confronted with the ultimate meaninglessness of life and probably therein lies the message from the flag bearers of nothingness. in the course 
of the narration there is a line that puzzles the reader: " That everything people believed to be true was a lie " [180]

In one of Unni's cartoons described in the book involves the appearance of an envelope which has the meaning of life written inside, and everyone laughs when they read it. Here the author often lampoon the selfimportance of people and the absurdity of the narratives we create for ourselves.

\section{3. Search for Meaning / Truth}

Manu Joseph is utterly brilliant in this sophomore novel where the story unfolds with the father trying to uncover the reason behind his son's death which results in the search for meaning of life. And during this process, he takes the reader for a journey through the 90's Madras. Ousep comes across many truths/half-truths, learns things about his son which he never knew and has a major impact on his family and neighbours due to this relentless search for the truth

This search is couched in the maze of moments devoid of any final meaning or truth: "It is as if the tired charade of human life with its great pursuits and history and wounds and deep convictions has collapsed, and the world has been suddenly revealed as a place that has no point, that does not need the hypothesis of meaning to explain its existence". [181] There is a single-mindedness about Joseph's narrative that keeps the reader interested and attentive despite the gloom. A father compulsively seeks the reason for his young son's suicide; his wife wrestles with a mentally-debilitating memory; their younger son struggles to make sense of a bewildering world. The search for answers and its impact on the family and unni's acquaintances occupy the whole book. The book also proves that the search for the truth in another person can also sometimes be like a mirror into one's own motivations.

Of the sixty-four cartoons and comics drawn by Unni, "there is a disproportionate number of comics that lampoon the human search for the meaning of life". [182] The author seems to have done substantial research talking to neuro-scientists about the nature of mental disorders. One of the central themes running through the book is the possibility that the pursuit of Truth, in most cases, could be just a mental disorder and Enlightenment, just a schizophrenic condition! There is an interesting observation that he draws on the Misanthrope who searches for truth:

It is the misanthrope who alone has clarity. By standing outside the huddles of man, he sees a lot, and what he often sees is the evidence that people are not as smart as dogs think they are. And he wants to see it time and again. In the fog of ambiguities and mysteries, he desperately searches for truths because truth usually shows humanity in a poor light. [183]

There are people in this world who wander through their entire lives searching for meaning, searching for an answer. For all his humour, Unni was probably among them. Could it be that Ousep, too, is searching, seeking an end that probably does not exist. Is he, too, "searching for As noted early on: an illusory truth" [184]

That a mystery must have a resolution is obviously not a requirement of nature. It is, in fact, another deceit of writers. A plot device, like the idea of a beginning, a middle and an end. In the real world, are mysteries usually solved ? What are the chances? Was there ever a person in this world who went in search of an answer and actually found it? [185]

Driving the plot is Ousep's reconstruction of Unni's search for ultimate truth in a world where truth might be just a shared delusion. Ousep gradually learns Unni's philosophy through the few people who knew him - the idea that happiness is inescapable, that delusions breed - but Joseph's novel suggests that truth and beauty are potentially lethal, and the pursuit itself may be a form of delusion. The novel attempts to prove that "the pursuit of truth, in most cases, is a mental disorder" [186] and that love of art and Enlightenment and all that we think good are " a form of evil" [187]

\subsection{Truth and Delusion}

Joseph's foray into the world of delusions is delightful. In an interview he stated, "I have always been fascinated by the power of delusion in people who are clear-headed in other ways." [188] Beta, one of his fellow cartoonists speculates on Unni's interest in delusions: " What if the meaning of life was realised ages ago by early man, the whole business of truth settled, and the world today is merely a post-enlightment residue?" [189]

There are also some profound statements about Life and Truth coming from Unni:

He said every delusion has an objective, and the objective of a delusion is not merely to colonize one brain but to transmit itself to as many brains as possible. That is the purpose of every delusion, that is how a delusion survives, that is how it succeeds. By spreading, 
maximizing its colony, like a virus. According to Unni, any philosophy that can be transmitted to another person is a delusion. If two people believe in the same idea of truth, it is a delusion ...Truth is a successful delusion." [190] 8

At one point, Unni elaborates his theory on how ordinary men manage to cast such a spell on women who are much cleverer than them. He says: " ...the fundamental quality of a delusion is that it is contagious. The very purpose of every delusion is to transmit itself to other brains. That is how a delusion survives. On the other hand, truth can never be transmitted. It does not travel from one brain to another. Movement is a quality of delusion alone...." [191]

Ousep's reconstruction of Unni's search for ultimate truth in a world where truth might be just a shared delusion is given sufficient space in the novel . Ousep gradually learns Unni's philosophy through the few people who knew him - the idea that happiness is inescapable, that delusions breed - but Joseph's novel suggests that truth and beauty are potentially lethal, and the pursuit itself may be a form of delusion.

Elsewhere, the neuroscientist Dr.Iyengar says, "....the society of neuroscientists would admit that all evidence points to the fact that God is a figment of man's delusion, yet believers in God, who form most of humanity, cannot be considered delusional. This is a ridiculous position..." [192]

Joseph makes a distinction between a delusion and a lie. " A delusion is many times more powerful than a lie". [193] Here the distinction is between a successful saint and a fraud. A god-man succeeds in convincing half the country that he is a god while a magician fails. The narrator says that all our gods, from the beginning of time, have been men with psychiatric conditions. They passed their delusions on to posterity. " God and believer were then locked in the Folly of the Two, they still are" [194]

The very objective of delusion is " to spread, to colonize other neurological systems" [195]

Ultimately the novel can be seen as a philosophical meandering that explores and questions how well you really know your own family and how much delusion lies in the pursuit of truth, beauty, and happiness, as Unni believed.

\subsection{Normality and Madness}

In Serious Men and particularly in The Illicit Happiness of Other People he plays on the fine line between Normality and madness. It seems like one of the most fruitful territories for a novelist to explore, in these days of hyper-communicative intelligence, over-verbalization, and convenient technologies of expressiveness that encourage and publicize both normality and madness. The establishments and society at large always fears the unusual and stamps it as mad and then, struggles to docile the individual into the standardised. The narrator aptly puts it this way: " The tragic defeat of the unusual, and so the triumph of the normal". [196] But Joseph clarifies his position in an interview with Shivani : "I think almost everybody is mad. I really believe that. Very few people in the world are sane, one of the subjects of my next book. You look at the average person--his or her beliefs, the huge cathedrals built for them, the religions that maintain order, the rubbish that people believe in, the imbeciles who can influence millions, the rover on Mars searching for water-it is very obvious to me that most people are actually mad. ... The struggle of humanity to achieve clarity is what all art is about. [197]

Ousep on entering the house of Mythili feels suffocated by its adherence to the expected normality of a middle class home. ' It has all the fragrance of all good homes, the smell of steam and herbs and invisible jasmines, and the faint memory of incense. The smell of moderate people. These are the people who do everything that they are supposed to do. It is, in fact, bizarre that they have only one child and not two." [198]

Ousep also makes fun of the self-subjugated but idealised normalisations of 'alpha males'. 'That is how alpha males became endangered. Their sons decided that they would not become their fathers, they would be decent men, they will not sleep with strangers through the night, they would instead wipe baby shit, they would know at all times the ages of their children and the names of their teachers, they would buy curtains, they would transfer food from large bowls into smaller bowls and put them in fridge, they would not be their fathers. In a world full of new men who did not want to be their fathers, what chance did alpha males have?' [199]

\subsection{Gaze and Repressed Sexuality}

Manu Joseph's fiction, like the Great Tradition of Western art, is full of men looking at women - and perhaps inevitably, women watching themselves being looked at. In his first book, Serious Men, the X-ray gaze of Ayyan Mani reduces pretty much every woman to her bra straps and panty lines. The theme appears early on in Joseph's The Illicit. As the characters take centre stage, we delve into the secret life of the household. We learn of its idiosyncracies: for example, Mariamma's talking to the walls, and Thoma's longing for Mythili, the Tamil Brahmin girl next door.The book with the underlying tone of thwarted sexuality and sexual desperation is a novel of a culture unable to deal with sexual desire. The children - and often young adults - remain uninformed about basics, leaving boys mystified. Young Thoma is just beginning to have these stirrings, but is ill-equipped 
to deal with them - and, like all the others in the novel, has no one with whom to discuss them. Yet side by side with this naïveté is a pervasive culture of sexual harassment. In a scene that sums it all up, Thomas watches as a man slap the bottom of the neighbour-girl, Mythili, who does not react; Thoma does not understand the nature of the act, and is surprised when his mother, whom he is walking with, clobbers the man with a coconut when he passes by them as he continues down the street; the man does not react to being hit -- continuing the charade of not acknowledging what had just happened which only the slightly mad Mariamma is willing to make a fuss about.

Sexual urges, societal stifling of them, and then widespread sexual harassment which everyone turns a blind eye to are pervasive in the novel, a fundamental flaw in this society that Joseph wants to address here. He manages not to let it overwhelm the book, but it is a difficult balance to strike. Joseph makes the reader reflect on the impact of repressed sexuality by interspersing a few typical incidents: his depiction of the "squads of college boys who board the packed buses' just to touch and poke the ladies, pulling the elastic of their underwear and releasing 'like a catapult' " [200] is a common sight in South India. Again, Ousep is at a bus stop when he sees a man pat a woman's buttocks. She thinks it is her little daughter (whose game has put the idea in the man's head). She does nothing. The man continues to pat her. "Ousep stares at the scene without opinion, without outrage. A man's hand on a woman's arse and the woman, yawning now, watching the world go by." [201]

Similarly, "Mythili's mother, like the mother's of all daughters, has the same pornographic eye as men. She sees sexual omens in anklets and skirts and flowing hair and long earrings that nod in the wind. They imagine, correctly, that the sex of their daughters is hidden in innocent places, as a soul of a vampire is stored in improbable objects." [202]

But the primal absurdity that Ousep attributes to that scene is replaced, as the book progresses, by a sharper, sadder, much more self-conscious look at ideas about sex, via a gaze that is sometimes Ousep's but more often his son Unni's. In fact, given the recurring nature of the theme in this book, Illicit might almost be read as a secret - or perhaps a public secret - history of our deeply dysfunctional relationship with sex.

The particular forms of misogyny and harassment that Joseph seeks out for his biting satire are those of Madras in the 1980s: a world in which a 12-year-old boy knows he can only fall in love with respectable girls, though he is not sure why, while his 17 -year-old brother is convinced - seemingly not entirely without basisthat every schoolboy he knows has committed a sexual crime. It is a world Joseph clearly knows well, and one he captures with dry-eyed wit and yet often affecting clarity.

The important women in Illicit - the marvellously memorable Mariamma, Unni's mother who either talks to Unni or to herself, and the more opaque beautiful teenager Mythili-are a great deal more sympathetic than any of the unidimensional women in Serious Men - the arrogant, hysterical Oparna, the grave, distant Lavanya, even the gullible, too-trusting Oja. Joseph cannot resist putting his own thoughts into the minds of his characters - hearing the 16-year-old Mythili hold forth bitingly on an imagined future husband who "will crack at least one entrance exam and one day have a nice house in a suburb of San Francisco" is fun, but scarcely believable.

Like Serious Men, Illicit is superbly plotted. It unfolds as a father's gaze into his 17 -year-old son's inexplicable suicide, "such a terrifying word in any language". Having discovered the last cartoons the boy left behind, and denied the comfort of having known him well when he was alive, the alcoholic Ousep becomes obsessed with the mystery of Unni's death, getting gradually sucked deeper and deeper into the dark world of a precocious 17-year-old. But though this is a book that is filled with precocious, supercilious, misanthropic young men, it also recognises, however dimly, the inevitable human need for other people.

And although it is often difficult to separate the cynical voices of these men-Ayyan in Serious Men, Unni and Ousep and so many of Unni's friends in Illicit-from the voice of the author, at least sometimes that unstinting cynicism is turned upon himself. "It is a misfortune to be in the presence of a writer, even a failed writer, to be seen by him, be his passing study and remain in his corrupt memory," goes a line in Illicit. It would indeed be a scary fate to be stowed away in Manu Joseph's "corrupt memory".

\subsection{The Other}

Here everyone is interested in everybody else's world. However, for all the outsiders of the Chackos living in a Madras housing colony, Chacko's family forms 'the other', characterised as the miserable, the unrecognised and sometimes the eccentric and who are essential for the creation of their own illusion of the rational, normal and the sane. Ousep's antics, Mariamma's unabashed craziness, and Thoma's timidity are enough to warrant gossip from neighbours. For this minority Catholic family living in Madras and living out the dichotomy of the self and the other raises the issues identity, alienation and difference.

Joseph's rich characters intersect in moments of tenderness, yet each continues along a path that gracefully highlights the titular Other and the emotional divides that separate individuals., Joseph's empathic prose deftly bridges those gaps. The novel follows Unni's brief life in search of what he believed to be the Ultimate Truth. We are taken through a maze of the many psychological posers that Unni and his buddy Somen 
Pillai create before arriving at the reason behind Unni's decision to commit suicide. Some of the best lines of the book are devoted to Ousep, through whom Joseph captures a whole generation of literary Malayalee men:

In time, Ousep stops loving home, he becomes the other men, men who sink into the company of other men, the veteran husbands, men who drink late into the night with their friends, men with frail thighs who have never played football but talk about football, and at other times about the superiority of Marx over Keynes, and about the unattainable prose of the new Spanish writers. [203]

This is an astonishingly accurate paragraph and Ousep grows more real even as the reader recognises him as the representative of a type. Though Ousep is a solitary man during the day, he belongs to other men at night: "He does not have to buy his drinks, he has many friends who want to buy him liquor... Because what men find most endearing in other men are their tragic flaws. That is why alcoholics never run out of friends. In the light of day, Ousep is too strong, too clever, a solitary man. But when night falls he belongs to all men" [204]

Ousep's newfound determination to understand the reason for his son's death after a piece of mail containing one of Unni's final cartoon sketches is returned to their home also does nothing to bridge the ostracized family back into the community. But perhaps the biggest gap to fill is the one that reigns within the Chacko's own household as Ousep goes out and speaks to the few people who knew Unni well-the 'other' in the title of this book.

Unni too confronts the other in his search for others like him and this leaves him pointless and desperate : " He believes that there are more like him in the world and begins to search for them. He searches among the seemingly normal, and among the mad. He searches for the unnaturally happy and the inexplicably sad. But he finds no one who is like him". [205]

\section{Conclusion}

The Illicit is a drastic shift from Serious Men, though the constant sense of uneasiness remains. Yet the reader cannot deny the pleasure it provides being part of the Chackos: their victories delights, losses upsets, strengths fuels, weaknesses embarrasses and revelations astounds as every nuances of the plot gets unravelled.

Its strengths deserved need praiseworthy mentions like the brilliant way in which the suspense was maintained, in the way Unni was portrayed piece by piece from scattered descriptions, in the way the Chacko family - in its middle class penury, in its shambles of a family unit, in its unspoken social ostracization - was caustically presented through the family's minute and major losses. One might at times feel a crack line developing in one's heart while going through the tragicomedy, yet feel curiously pleasant. This display of just how damaged the characters were, without any contrived indulgence into emotional porn, runs tightly alongside Ousep's investigation of Unni's personality that is shattering in itself as an idea.

Also, Joseph continued a largely sexist portrayal of women from his previous offering, but compared to that novel, his only intention perhaps is to take the reader into the innocent depravity of a thinking male, before he becomes evil enough to cross acceptable boundaries. Joseph dexterously handles kids too and brings great life to their side-roles dominated in large parts by grades and performance in entrance exams. Reading parts involving Thoma were a pure delight, in the way he perceives the world through his naive adolescence and experiences tragedy through the prism of confused comprehension, which goes a long way in promising a faith that he might emerge out of his elder brother's world-view built on bleak pessimism and cynicism feeding off eclectic philosophies. This book reads like a strong piece of music that begins enticingly, makes you wonder about the whole idea of the music in the middle and in the end, delivers a resounding crescendo in powerful dense rhythms.

Designed to challenge the reader with delicate, yet probing questions regarding both morality and spirituality, The Illicit is steeped in the philosophical leaving much to the intelligence of the reader to find a definitive answer concerning the central mystery it presents. Does the reader think Unni Chacko did what he did because he realised that he had become Philipose? The book offers sufficient data for many similar assumptions. The reader discovers Unni through the eyes of his classmates, his friends, eccentric cartoonists, a nun who took the vow of silence, a psychiatrist, a physics teacher and finally the son's mother. And in the process relishes the small, humorous idiosyncrasies of the various characters peppered throughout the novel, traits that are at once real and brilliantly witty. The Indian middle class , replete with the funny quirks and the not-so-funny perversions also get a realistic treatment in the process

Joseph's characters effortlessly fly off the page and into the reader's heart as they struggle to come to terms with how to move forward in a world that's now forever missing a key piece. Joseph's language is just as beautiful as his subjects, and in a world that has become increasingly obsessed with focusing on studying those we've labelled "damaged" or "dysfunctional," Illicit Happiness becomes a welcome reminder that the opposite side of the spectrum can be just as interesting, and perhaps surprisingly to some, far more appealing ground to explore. 
Just as much as this novel is about grief and trauma, it is also about family dynamics and the idea that, even though you may live with people and see them on a daily basis, we all have the ability to conceal our deepest truths and desires. As Ousep searches for the desires and truths of his son, he neglects to tend to his living relatives. He is so obsessed with solving the mystery of chosen death that he overlooks the importance of chosen life. In any case,Manu's book is sophisticated entertainment, a gift to the discerning reader.

\section{Reference}

[1]. Joseph, Manu . The Illicit Happiness of Other People, Noida: HarperCollins . 2012.

[2]. Joseph, Manu .Serious Men, New York: W.W. Norton, 2010.

[3]. Sacks, Sam. "Giving Hope to the American Short Story" Jan. 4, $2013 \quad 3: 17$ p.m. ET. http://online.wsj.com/news/articles/SB10001424127887324374004578217702498416858

[4]. Adiga, Aravind. The White Tiger, New York: Free Press, 2008

[5]. Dasgupta, Rana. Solo, HarperCollins e-books, 2009.

[6]. Hanif, Mohammed . A Case of Exploding Mangoes, A KNOPF e-books, 2009.

[7]. Shivani, Anis : Manu Joseph, Author of "Serious Men" (Interview) Posted: 09/18/10 08:30 AM ET http://www.huffingtonpost.com/anis-shivani/manu-joseph-india b 674544.html)

[8]. Fae Myenne Ng. Bone New York: Hyperion, 1993

[9]. The Illicit 5

[10]. The Illicit 17

[11]. The Illicit 182

[12]. The Illicit 82

[13]. Shivani, Anis : Manu Joseph, Author of "Serious Men" (Interview) Posted: 09/18/10 08:30 AM ET http://www.huffingtonpost.com/anis-shivani/manu-joseph-india_b_674544.html)

[14]. The Hindu. "World's Literature Festival in Norwich, England" on June 23, 2011: http:// www. the hindu.com /arts/books/ article 389247. ece

[15]. Mahboob, Tahiat : "Interview: Novelist Manu Joseph Explores Family Happiness, 'Illicit' and Otherwise" January 7th, 2013 http://asiasociety.org/blog/asia/interview-novelist-manu-josep h-explores-family-hppiness-illicit-and-otherwise

[16]. Shivani, Anis : Manu Joseph, Author of "Serious Men" (Interview) Posted: 09/18/10 08:30 AM ET http://www.huffingtonpost.com/anis-shivani/manu-joseph-india b 674544.html)

[17]. Singh, Jai Arun “I'm a cartoonist who can't draw" September 18, 2012 14:34 IST cartoonist-who-cant-draw/article3892427.ece

[18]. Sibal, Prachi. 'I don't try to be satirical at all'31 October 2012 12:42

[19]. Sibal, Prachi. 'I don't try to be satirical at all'31 October 2012 12:42

[20]. Sibal, Prachi. 'I don't try to be satirical at all'31 October 2012 12:42

http://www.thehindu.com/books/im-a-

[21]. Singh, Jai Arun “I'm a cartoonist who can't draw" September 18, 2012 14:34 IST cartoonist-who-cant-draw/article3892427.ece

[22]. Kundera, Milan. The Unbearable Lightness of Being, Trans. Michael Henry Heim. HarperCollins, 1985.

[23]. Mitchell, David. The Thousand Autumns of Jacob de Zoet, New York:Random House, 2010

[24]. Bhattacharya, Rahul. The Sly Company of People Who Care, Penguin Books, 2012.

[25]. Gupta, Anveshi "Conversation with Manu Joseph" http://isahitya.com/index.php/english-sahitya/englishconversation-with-manu-joseph

[26]. The Illicit 29

[27]. The Illicit 82

[28]. Netzer, Jaime. "Manu Joseph: The Illicit Happiness of Other People" January 7, $2013 \quad$ https://www.kirkusreviews.com/book reviews/manu-joseph/illicit-happiness-other-people

[29]. The Illicit 48

[30]. The Illicit 50

[31]. The Illicit 26

[32]. The Illicit 59

[33]. The Illicit 52

[34]. The Illicit 10

[35]. The Illicit 50

[36]. The Illicit 23

[37]. The Illicit 24

[38]. The Illicit 26

[39]. The Illicit 52

[40]. The Illicit 13

[41]. The Illicit 6

[42]. Nair, Anitha. Lessons in Forgetting, New Delhi: HarperCollins, 2010

[43]. The Illicit 70

[44]. The Illicit 123

[45]. The Illicit 22

[46]. The Illicit 22

[47]. The Illicit 71

[48]. The Illicit 47

[49]. The Illicit 99

[50]. The Illicit 3

[51]. The Illicit 5

[52]. The Illicit 27

[53]. Joseph, Manu. " Memories of a Stud" OPEN $\quad$ Magazine, $12 \quad$ September 2009. http://www.openthemagazine.com/article/living/memories-of-a-stud 
[54]. Joseph, Manu. " Indian Spiritualism Made for the Modern Age" The New York Times, July 6, 2011. http://www.nytimes.com/2011/07/07/world/asia/07iht-letter07.html? r=0

[55]. Ramachandran, V.S. Phantoms in the Brain, New York: HarperCollins, 1998.

[56]. Singh, Jai Arun "I'm a cartoonist who can't draw" September 18, 2012 14:34 IST $\quad$ http://www.thehindu.com/books/im-acartoonist-who-cant-draw/article3892427.ece

[57]. The Illicit 7

[58]. Gupta, Anveshi "Conversation with Manu Joseph" http://isahitya.com/index.php/english-sahitya/english- literature/523conversation-with-manu-joseph

[59]. The Illicit 41

[60]. The Illicit29

[61]. The Illicit.29

[62]. The Illicit29

[63]. The Illicit 98

[64]. The Illicit 6

[65]. The Illicit74

[66]. The Illicit76

[67]. Singh, Jai Arun “I'm a cartoonist who can’t draw” September 18, 2012 14:34 IST $\quad$ http://www.thehindu.com/books/im-acartoonist-who-cant-draw/article3892427.ece

[68]. Sibal, Prachi. 'I don't try to be satirical at all'31 October 2012 12:42 http://talkmag.in/cms/culture/books? start=14

[69]. Singh, Jai Arun "I'm a cartoonist who can't draw" September 18, 2012 14:34 IST http://www.thehindu.com/books/im-acartoonist-who-cant-draw/article3892427.ece

[70]. Davidson, G.W. M.A. Seaton and J. Simpson (ed.) Chambers Concise 20th Century Dictionary, New Delhi:1986, Allied publishers, p.39.

[71]. Baldick, Chris. The dictionary of Literary Terms, 1990 OUP p. 11.

[72]. The Illicit 15

[73]. The Illicit 48

[74]. The Illicit 59

[75]. The Illicit 57

[76]. The Illicit 3

[77]. The Illicit 5

[78]. Gurung, Rita. The Archetypal Antihero in Postmodern Fiction, New Delhi, Atlandic, 2002. p.19.

[79]. The Illicit 14

[80]. The Illicit 61

[81]. Rushdie, Salman. Joseph Anton, New York: Random House, 2012. p.74.

[82]. The Illicit 100

[83]. The Illicit 100

[84]. The Illicit 104

[85]. The Illicit 104

[86]. The Illicit 105

[87]. The Illicit 105

[88]. The Illicit 60

[89]. The Illicit 6

[90]. The Illicit 337

[91]. The Illicit 341

[92]. The Illicit 37

[93]. The Illicit 37

[94]. The Illicit 44

[95]. The Illicit 40

[96]. The Illicit 94

[97]. The Illicit 95

[98]. The Illicit 105

[99]. The Illicit 3

[100]. The Illicit 89

[101]. The Illicit 34

[102]. The Illicit 28

[103]. The Illicit 42

[104]. The Illicit 30

[105]. The Illicit 58

[106]. The Illicit 98

[107]. The Illicit 103

[108]. The Illicit 104

[109]. Singh, Jai Arun "I'm a cartoonist who can't draw" September 18, 2012 14:34 IST $\quad$ http://www.thehindu.com/books/im-acartoonist-who-cant-draw/article3892427.ece

[110]. Singh, Jai Arun "I'm a cartoonist who can’t draw" September 18, 2012 14:34 IST http://www.thehindu.com/books/im-acartoonist-who-cant-draw/article3892427.ece

[111]. The Illicit 94

[112]. The Illicit 112

[113]. The Illicit 112-113

[114]. The Illicit 111

[115]. The Illicit 113

[116]. The Illicit 113

[117]. The Illicit 117

[118]. The Illicit 45 
[119]. Netzer, Jaime. "Manu Joseph: The Illicit Happiness of Other People" January 7, 2013

https://www.kirkusreviews.com/bookreviews/manu-joseph/illicit-happiness-other-people

[120]. Netzer, Jaime. "Manu Joseph: The Illicit Happiness of Other People" January 7, 2013 reviews/manu-joseph/illicit-happiness-other-people

[121]. Netzer, Jaime. "Manu Joseph: The Illicit Happiness of Other People" January 7, 2013 reviews/manu-joseph/illicit-happiness-other-people

[122]. The Illicit 4

[123]. The Illicit 20

[124]. The Illicit 296-297

[125]. The Illicit 5

[126]. The Illicit 10

[127]. The Illicit 31

[128]. The Illicit 32

[129]. The Illicit 114

[130]. Bell, Madison Smart. Year of Silence, Penguin Books, 1987.

[131]. Singh, Jai Arun "I'm a cartoonist who can’t draw" September 18, 2012 14:34 IST cartoonist-who-cant-draw/article3892427.ece

[132]. Gupta, Anveshi "Conversation with Manu Joseph" http://isahitya.com/index.php/english-sahitya/english- literature/523conversation-with-manu-joseph

[133]. The Illicit 240

[134]. The Illicit 70

[135]. The Illicit 66

[136]. The Illicit 66-67

[137]. The Illicit 4

[138]. The Illicit 28

[139]. The Illicit 36

[140]. The Illicit 37

[141]. The Illicit 12

[142]. The Illicit 51

[143]. The Illicit 53

[144]. The Illicit 54

[145]. The Illicit 58

[146]. Singh, Jai Arun “I'm a cartoonist who can't draw" September 18, 2012 14:34 IST $\quad$ http://www.thehindu.com/books/im-acartoonist-who-cant-draw/article3892427.ece

[147]. Singh, Jai Arun "I'm a cartoonist who can't draw" September 18, 2012 14:34 IST $\quad$ http://www.thehindu.com/books/im-acartoonist-who-cant-draw/article3892427.ece

[148]. Singh, Jai Arun “I'm a cartoonist who can't draw" September 18, 2012 14:34 IST http://www.thehindu.com/books/im-acartoonist-who-cant-draw/article3892427.ece

[149]. Campbell, Joseph. The Hero with a Thousand Faces, , Meridian Books, 1949.

[150]. Conrad, Joseph. Lord Jim, Harmondswort:, Penguin 1949. p.214

[151]. The Illicit 47

[152]. The Illicit 26

[153]. The Illicit 99

[154]. The Illicit 99

[155]. The Illicit 99

[156]. The Illicit 99

[157]. The Illicit 99

[158]. The Illicit 99

[159]. American Psychiatric Association. Diagnostic and Statistical Manual of Mental Disorders, 2013. p.15.

[160]. Mahboob, Tahiat : "Interview: Novelist Manu Joseph Explores Family Happiness, 'Illicit' and Otherwise" January 7th, $2013 \mathrm{http}: / /$ asiasociety.org/blog/asia/interview-novelist-manu-josep h-explores-family-h ppiness-illicit-and-otherwise

[161]. The Illicit 282

[162]. Gupta, Anveshi "Conversation with Manu Joseph" http://isahitya.com/index.php/english-sahitya/english- literature/523conversation-with-manu-joseph

[163]. Singh, Jai Arun "I'm a cartoonist who can't draw" September 18, 2012 14:34 IST $\quad$ http://www.thehindu.com/books/im-acartoonist-who-cant-draw/article3892427.ece

[164]. The Illicit 105

[165]. The Illicit 98

[166]. The Illicit 72

[167]. The Illicit 82

[168]. The Illicit 11

[169]. Netzer, Jaime. "Manu Joseph: The Illicit Happiness of Other People" January 7, $2013 \quad$ https://www.kirkusreviews.com/bookreviews/manu-joseph/illicit-happiness-other-people

[170]. The Illicit 21

[171]. The Illicit 21

[172]. The Illicit 211

[173]. The Illicit 23

[174]. The Illicit 244

[175]. The Illicit 216

[176]. The Illicit 18

[177]. The Illicit 18

[178]. 178. Grishpan, Renny. " Manu Joseph: The Illicit Happiness of Other People" http://asiasociety.org/new- $\quad$ york/manujoseph-illicit-happiness-other-people January 10, 2013

[179]. Hassan, Ihab. Radical innocence, Prnceton University Press, 1961. p 62. 
[180]. The Illicit 179

[181]. The Illicit 179

[182]. The Illicit 19

[183]. The Illicit 11

[184]. The Illicit 102

[185]. The Illicit 23

[186]. The Illicit 335

[187]. The Illicit 21

[188]. Singh, Jai Arun "I'm a cartoonist who can't draw" September 18, 2012 14:34 IST http://www.thehindu.com/books/im-acartoonist-who-cant-draw/article3892427.ece

[189]. The Illicit 21

[190]. The Illicit 22

[191]. The Illicit 192

[192]. The Illicit 282

[193]. The Illicit 280

[194]. The Illicit 280

[195]. The Illicit 281

[196]. The Illicit 281

[197]. Shivani, Anis: Manu Joseph, Author of "Serious Men" (Interview) Posted: 09/18/10 08:30 AM ET http://www.huffingtonpost.com/anis-shivani/manu-joseph-india_b_674544.html

[198]. The Illicit 28

[199]. The Illicit 281

[200]. The Illicit 281

[201]. The Illicit 281

[202]. The Illicit 281

[203]. The Illicit 281

[204]. The Illicit 281

[205]. The Illicit 281 